UNIVERSIDADE DE SÃO PAULO

FACULDADE DE MEDICINA DE RIBEIRÃO PRETO

DEPARTAMENTO DE BIOLOGIA CELULAR, MOLECULAR E BIOAGENTES

PATOGÊNICOS

Infecção por rinovírus em células linfoides de tonsilas humanas

Ribeirão Preto 


\title{
Infecção por rinovírus em células linfoides de tonsilas humanas
}

\author{
Versão Original
}

Tese apresentada ao Programa de Pós-Graduação em Biologia Celular e Molecular e Bioagentes Patogênicos da Universidade de São Paulo para a obtenção do título de Doutor em Ciências.

Área de Concentração: Biologia Celular e Molecular e Bioagentes Patogênicos.

Orientador: Prof. Dr. Eurico de Arruda Neto

Ribeirão Preto 
Autorizo a reprodução e divulgação total ou parcial deste trabalho, por qualquer meio convencional ou eletrônico, para fins de estudo e pesquisa, desde que citada a fonte.

Ficha catalográfica

Martins, Ronaldo Bragança

Infecção por rinovírus em células linfoides de tonsilas humanas. Ribeirão Preto, 2017.

60 p. : il. ; $30 \mathrm{~cm}$

Tese de Doutorado, apresentada à Faculdade de Medicina de Ribeirão Preto/USP. Área de concentração: Biologia Celular e Molecular e Bioagentes Patogênicos.

Orientador: Arruda Neto, Eurico.

1. Rinovírus. 2. Vírus Respiratório. 3. Tonsilas. 4. Persistência. 


\section{Ronaldo Bragança Martins Júnior}

\section{Infecção por rinovírus em células linfoides de tonsilas humanas}

Tese de doutorado apresentada ao programa de Pósgraduação em Biologia Celular e Molecular da Faculdade de Medicina de Ribeirão Preto- Universidade de São Paulo, para obtenção do título de Doutor em Ciências.

Aprovado em:

Banca examinadora

Prof. Dr

Julgamento

Prof. Dr

Julgamento

Prof. Dr

Julgamento

Prof. Dr

Julgamento

Prof. Dr

Julgamento
Instituição:

Assinatura:

Instituição:

Assinatura:

Instituição:

Assinatura:

Instituição:

Assinatura:

Instituição:

Assinatura: 


\section{Agradecimentos}

Chega o momento de demonstrar em poucas palavras toda minha gratidão por aqueles que me ajudaram de alguma forma a alcançar o título de Doutor em Ciências.

Aos meus pais e meu irmão, os maiores entusiastas em relação a minha busca ao título de Doutor em Ciências, pela confiança inabalável, pelo carinho e incentivo constante ao longo desses quatro anos longe de casa e por serem meus maiores exemplos de dedicação e perseverança.

Ao Professor Eurico de Arruda Neto, pela orientação primordial, por cativar o melhor em mim, pelo entusiasmo científico, pela amizade, pelo grande exemplo de profissional edônio e carismático. Gratidão por me ensinar o significado de "think outside the box" na vida acadêmica.

Aos velhos amigos, Lucas Rezende e Fernanda Amorim, pelo crucial suporte e companherismo no início do meu doutorado.

Aos colegas do laboratório de Patogenese Viral da Faculdade de Medicina de Ribeirão Preto e do Centro de Pesquisa em Virologia, pela amizade e gentileza, pelo convívio enriquecedor e pelas coloborações diretas e indiretas durante o trabalho desenvolvido. Gratidão especial para com Maria Lúcia Silva (técnica do nosso laboratório), Miriã Criado, Talita Bianca e Luciano Luna (pós-doutorandos), a parceria dentro e fora do laboratório foi um privilégio.

Aos professores e colaboraderes do Departamento de Oftalmologia, Otorrinolaringologia e Cirurgia de Cabeça e Pescoço, pela colaboração direta com o projeto e pelas discussões científicas diante dos resultados.

Aos funcionários do Departamento de Biologia Celular e Molecular Bioagentes Patogênicos da Faculdade de Medicina de Ribeirão Preto, pela colaboração, direta ou indireta.

Ao CNPq, FAEPA e FAPESP, pelo suporte financeiro, essencial para a conclusão desse trabalho. 
"Science is our best current approximation of the way things work. You cannot do science unless you believe there is a discernable truth inherent to the arrangement of our tangible world." (Palmenberg, 2016. p.1) 


\section{Resumo}

MARTINS,R.B. Infecção por rinovírus em células linfoides de tonsilas humanas. 2017. 60p. Tese de Doutorado - Faculdade de Medicina de Ribeirão Preto. Universidade de São Paulo, 2017.

Rinovírus (RV) é freqüentemente detectado nos tecidos tonsilares e nas secreções de nasofaringe de pacientes com doença adenotonsilar crônica, sem sintomas de infecção respiratória aguda (IRA). O objetivo deste estudo foi investigar a infecção por rinovírus em tonsilas humanas, com base em dois aspectos: infecção in vivo de células linfóides de tonsilas humanas naturalmente infectadas; e infecção ex vivo de células dissociadas desses tecidos inoculadas com rinovírus, visando a contribuir para elucidar possíveis mecanismos de infecção em amígdalas palatinas e adenóides humanas. De um total de 104 pacientes com doenças adenotonsilar crônicas, $21.1 \% \quad(22 / 104)$ e $42.3 \% \quad(44 / 104)$ apresentaram respectivamente amígdalas palatinas e adenóides positivas para RV por PCR. A replicação viral foi confirmada por hibridização in situ com sonda para intermediário replicativo nas regiões internas e externas aos folículos linfóides de amígdalas e adenóides, bem como em porções do epitélio ciliado de adenoides, e apenas raramente nas células epiteliais escamosas de tonsilas palatinas. A presença e distribuição de proteína estrutural do capsídeo viral foi detectada por imunohistoquímica (IHQ), utilizando anticorpos contra proteínas estruturais virais VP1 e VP2 nas tonsilas positivas para RV por qPCR. Os resultados indicaram marcação positiva tanto na superfície (epitélio), quanto em regiões extrafoliculares e centros germinativos. Em seguida, foi possível verificar a co-localização da marcação positiva da proteína estrutural VP2 de RV com marcadores linfocitários de membrana. Células CD4 + e CD20 + apresentaram marcação positiva para VP2 verificada usando estratégia de 'sequential immuno-peroxidase labelling and erasing' (SIMPLE). Culturas primárias de células linfomononucleares (CLMN) de tonsilas sabidamente negativas para RV por PCR, foram infectadas in vitro, com RV (MOI=1). A replicação de RV foi titulada por TCID50, mostrando aumento inicial $(24 \mathrm{~h})$ e subsequente queda após 48 horas. Por IF observamos que os fenótipos de CLMN infectadas com RV in vitro foram células T CD4 + e B, mas também com células CD8 +, CD56 + e CD33 +. RV não infectou células CD123 +. RV foi isolado em WI38 e HeLa a partir de tecidos e secreções de nasofaringe de pacientes com hipertrofia tonsilar sem sintomas de infecção respiratória aguda. Nossos resultados confirmam que tonsilas de pacientes sem sintomas respiratórios agudos podem ser reservatórios de $R V$, que infecta não somente epitélio, mas também CLMN (frequentemente linfócitos T CD4 + e linfócitos B). A detecção de RNA intermediário replicativo e proteínas estruturais VP1 e VP2 nas tonsilas hipertróficas, além do isolamento de vírus infeccioso a partir de tecidos e secreções nasofaríngeas, classificam tonsilas hipertróficas como sítios de infecção e replicação de RV, e sugerem que esses indivíduos hipertróficos são portadores assintomáticos de RV persistente, e podem ser importantes fontes de transmissão de RV na comunidade.

Palavras chave: Rinovírus, doença adenotonsilar crônica, adenoide, amígdala, Persistência. 


\begin{abstract}
MARTINS,R.B. Rhinovirus infection in lymphoid tissues from hypertrophic human tonsils. 2017. 60p. Tese de Doutorado - Scool of Medicine of Ribeirão Preto of University of São Paulo, Ribeirão Preto, Brazil, 2017.
\end{abstract}

The chronic adenotonsillar diseases are frequent otorhinolaryngologic conditions caused by chronic inflammation of adenoids and palatine tonsils. Rhinovirus (RV) is highly frequently detected in secretions, and tonsillar tissues from patients experience chronic tonsillar hypertrophy without symptoms of ARI, and our goal is to full understanding of viral infections in hypertrophic tonsillar tissues by RV. Of 104 enrolled patients with adenotonsillar chronic diseases, 21.1\% (22/104) and 42.3\% (44/104) had palatine tonsils and adenoids positive for RV by qPCR, respectively. RV Viral replication was confirmed by in situ hybridizations. Minus-strand RNA were detected in all tested samples ( 7 tonsils and 9 adenoids), and positive reactions were seen inside and outside of lymphoid follicles from tonsils and adenoids, in the ciliated epithelium of the adenoids and rarely in positive squamous epithelium cells from tonsils. The presence of viral structural protein VP1 and VP2 was detected within and outside of the lymphoid follicles from tonsils and adenoids, and also in epithelial cells from adenoids by immunohistochemistry (IHC). Later, by sequential immuno-peroxidase labelling and erasing protocol (SIMPLE), we saw co-localization of RV VP2 capsid protein staining with CD4 positive cells and CD20 positive cells. We confirmed that RV could infect primary culture of tonsilar mononuclear cells (TMNCs). Additionally, intracellular replication of RV in TMNCs, measured by TCID50 in HeLa cells, had an initial increase in the first 24 hours, and dropped at 48 hours post infection. Immunolocalization staining with anti-RV and TMNCs surface markers indicated that phenotypes of susceptible cells were T-cells both CD4+ and CD20+, but also, we saw co-localization of VP-2 protein with CD8+ cells, CD56+ cells and CD33+ cells. RV-16 couldn't infect CD123+ cell in our experiments. Finally, we were able to recover 4 rhinoviruses by inoculating WI-38 fibroblast cells and HeLa cells, confirming by the cytopathic effect and immunofluorescence positive staining with anti-VP1 antibody. Taken together, our results indicate that tonsils and adenoids of patients without ARI may be reservoirs of replicating human rhinovirus, infecting manly Tcells CD4+ and CD20+ B-cells. The high-frequency detection of RNA (-) and VP1 expression in tissues from patients with chronic adenotonsillar diseases, plus the isolation of infectious viral particles, suggests that these detected agents replicate in the adenotonsillar tissues and this specific sites may be important sources of transmission of RV in the community.

Keywords: Rhinovirus, chronic adenotonsillar disease, adenoid, tonsil, Persistence. 


\section{SUMÁRIO}

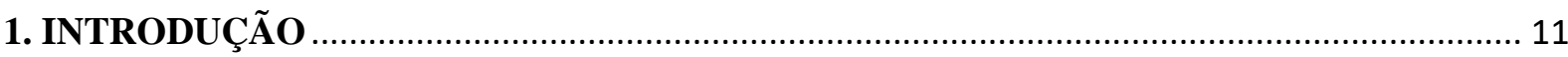

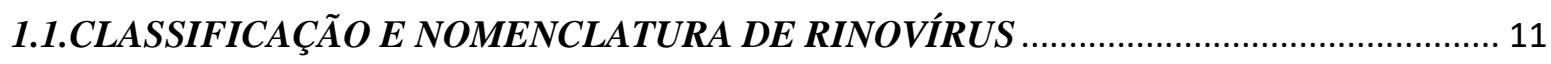

1.2.ORGANIZAÇÃO DA PARTICULA VIRAL E ESTRUTURA GENÔMICA …..................... 12

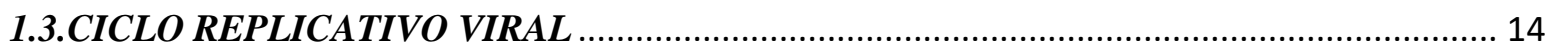

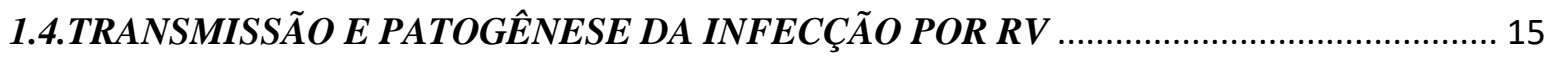

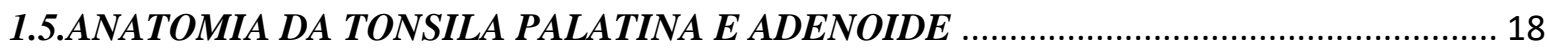

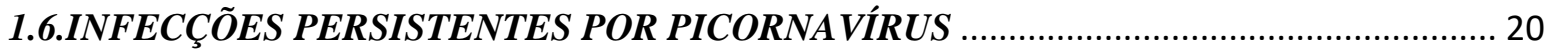

2.JUSTIFICATIVA

3.OBJETIVOS

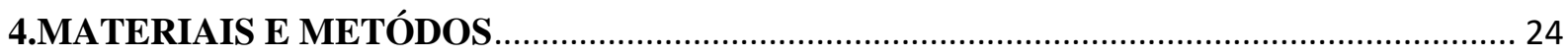

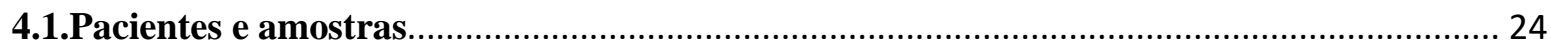

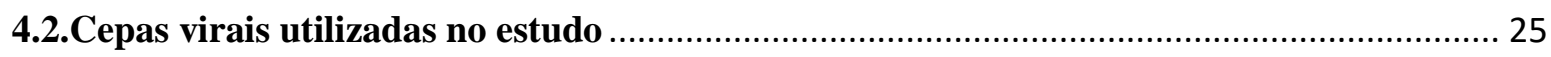

4.3.Detecção do genoma de Enterovirus por PCR em tempo real .......................................... 25

4.4.Determinação das espécies de rinovírus presentes em amígdalas e adenoides por

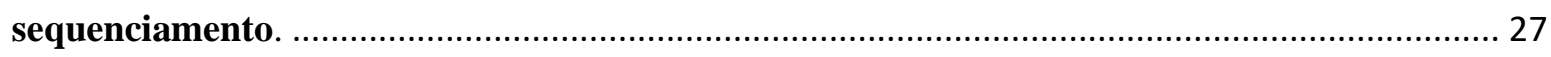

4.5.Imunohistoquímica para detecção da proteína estrutural de capsídeo de rinovírus.......... 28

4.6.Imunohistoquímica sequencial (SIMPLE) para proteínas virais e para marcadores de

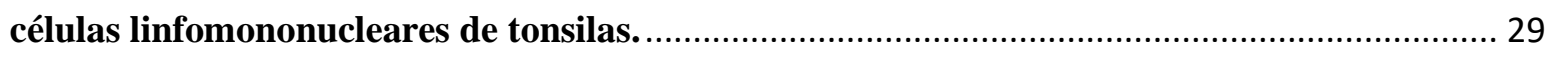

4.7.Hibridação in situ (ISH) para detecção do antigenoma de rinovírus com sonda de LNA.. 30

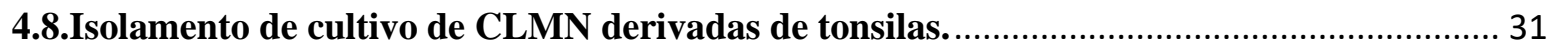

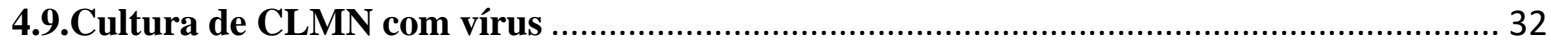

4.10.Titulação de RV em células linfocitárias infectadas........................................................ 32

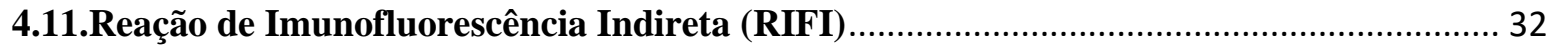

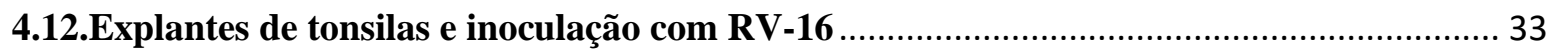

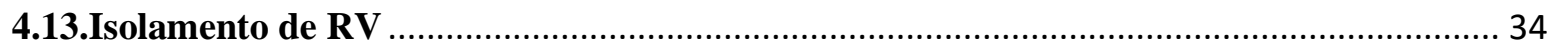

5.RESULTADOS

5.1.Frequência de detecção de genoma de RV e EV por qPCR …............................................. 35 
5.2.Localização de proteínas virais e determinação de fenótipos das células susceptíveis em adenoides e amígdalas naturalmente infectadas por $\mathrm{RV}$.

5.3.Localização da replicação de $R V$ em tonsilas humans por Hibridização in situ 39

5.4.Infecção ex vivo de explantes de tonsilas humanas por RV-16

5.5.Infecção e replicação de cutura primária de CLMN com RV 44

5.6.Isolamento de RV de tecidos e SNF. 46

6.DISCUSSÃO 49

7.CONCLUSÃO 54

8.REFERÊNCIAS BIBLIOGRÁFICAS 55 


\section{INTRODUÇÃO}

\subsection{CLASSIFICAÇÃO E NOMENCLATURA DE RINOVÍRUS}

Os rinovírus humanos (RV) atualmente encontram-se subdivididos em três espécies, a saber: RV-A, RV-B e RV-C, na família Picornaviridae, gênero Enterovirus (Jacobs et al., 2013). O gênero Enterovirus inclui 12 espécies, sete dessas classificadas como enterovírus humanos (enterovírus humanos A, B, C e D-EV; e rinovírus humanos A, B e C - RV). Como muitos vírus de RNA, os vírus do gênero Enterovirus têm propensão para variabilidade, resultando em grande número (>300) de sorotipos identificados (Palmenberg et al., 2009; International Commitee on Taxonomy of Viruses, 2015 release).

O chamado "resfriado comum", principal doença humana causada por rinovírus, é referido em relatos históricos desde a antiguidade. Inscrições egípcias com mais de 3.000 anos relatam, dentre centenas de doenças e desordens, uma em particular denominada Resh, posteriormente relacionada pelo arqueologista e egiptologista alemão George Ebers à presença de tosse e secreção nasal, que se acredita ter sido resfriado comum (Cohen, 1992). A natureza transmissível do 'resfriado comum' foi revelada em clássicos experimentos conduzidos em 1914 por Walter Kruse, no Instituto de Higiene de Leipzig, mediante inoculação de voluntários humanos com filtrados de secreções nasais de pacientes com resfriado (Dochez, 1936). Anos mais tarde, o elusivo agente etiológico do resfriado comum foi isolado por Sir Christopher Andrews, mediante a inoculação de culturas de tecido de pulmão embrionário humano com secreções respiratórias (Andrews et al., 1953). Novos isolamentos de rinovírus humano (RV) foram realizados a partir de lavados nasofaríngeos de pessoas com resfriado inoculadas em culturas de células de rim de macaco Rhesus (Price, 1956; Pelon et al., 1957) e, posteriormente, uma descrição do grupo viral foi feita por Tyrrell e Chanock, que propuseram o nome Rhinovirus, que fora originalmente sugerido por Sir Christopher Andrews, em alusão ao sítio primário da infecção (Turner, 2007).

Inicialmente, os sorotipos de RV determinados por reação com anticorpos neutralizantes foram divididos em dois grupos, com base na especificidade dos seus receptores celulares: $\mathrm{O}$ grupo major contendo 92 sorotipos que utilizam a molécula de adesão intercelular-1 (ICAM-I), e o grupo minor com 10 sorotipos (RV-1A, 1B, 2, 29, 30, 31, 44, 47, 49 e 62), que utilizam o receptor de lipoproteína de baixa densidade (LDLR), ou o receptor de 
lipoproteína de muito baixa densidade (VLDLR), ou ainda a proteína-1 associada à lipoproteína de baixa densidade (LRP1) como receptores de entrada (Arruda et al., 1992; Hofer et al., 1994; Marlovits et al., 1998; Lewis-Rogers et al., 2009). Contudo, seqüenciamento genômico total ou parcial nas regiões codificadoras das proteínas virais VP1 e VP4/VP2 de vários isolados clínicos de RV, possibilitou uma nova classificação filogenética, sugerindo uma divisão genotípica em duas espécies: RV-A e RV-B (Simmonds et al., 2010; Linder et al., 2012). Mais recentemente, o desenvolvimento de métodos de detecção molecular altamente sensíveis permitiu identificar uma nova espécie de rinovírus humano, denominado HRV-C, cujo receptor celular, precursor 3 relacionado à família das caderinas (CDHR3), foi recentemente identificado (Bochkov et al., 2015). Assim, conhecemse até o presente momento 166 tipos de RV, entre sorotipos e genotipos, a saber: 80 tipos de HRV-A, 32 tipos de HRV-B e 54 tipos de HRV-C (Gern \& Palmenberg, 2013; McIntyre et al., 2013; Jans \& Ghildyal, 2015).

\subsection{ORGANIZAÇÃO DA PARTICULA VIRAL E ESTRUTURA GENÔMICA}

Os RV são vírus desprovidos de envelope, cujo capsídeo tem simetria icosaédrica com diâmetro de 30nm, formado por 60 cópias de cada uma das quatro proteínas estruturais VP1, VP2, VP3 e VP4 (Figura 1) (Jans \& Ghildyal, 2015). As três primeiras proteínas localizam-se mais externamente, enquanto que VP4 é interna, exercendo papel de ancoragem do RNA genômico ao capsídeo viral (Turner, 2007). A superfície do vírion é formada por capsômeros pentaméricos constituídos por protômeros que são hetero-tetrâmeros das proteínas VP1 a VP4, e que convergem em platôs que formam vértices pentaméricos de proteínas VP1 adjacentes, e estes são rodeados por depressão denominada cânion (Figura 1A), delimitado principalmente por VP1. No assoalho do cânion há um bolso hidrofóbico (Figura 1B), que é alvo das principais drogas antivirais estabilizadoras de capsídeo (Racaniello, 2013).

O genoma de RV é constituído por uma fita simples de RNA de polaridade positiva [RNA(+)] com aproximadamente 7,2 Kb, monocistrônico, codificante de uma poliproteína que, por sucessivas clivagens proteolíticas, dá origem a 11 produtos gênicos. A região 5' não traduzida (5'NTR) do genoma de RV contém 600 a 1.200 nucleotídeos e há uma proteína covalentemente ligada à extremidade 5', a VPg (proteína viral genômica). A região 3' não

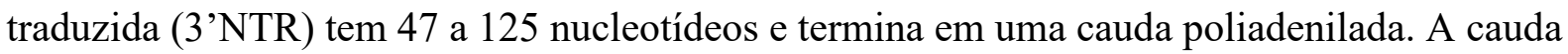
poli-A potencializa a tradução de mRNAs virais e, quando removida, o genoma se torna nãoinfeccioso. Correspondendo à cauda poli- A, o intermediário replicativo de RNA 

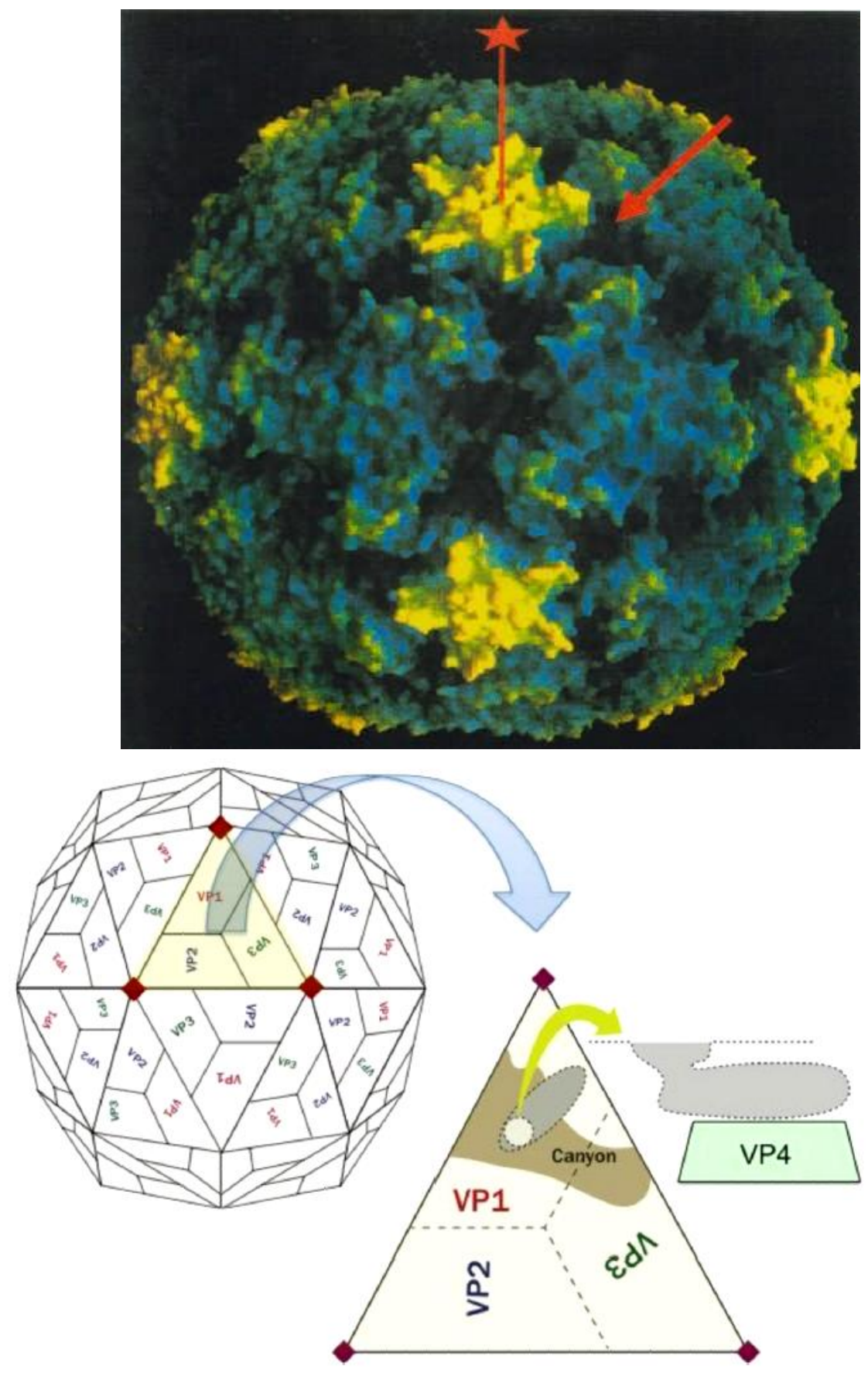

Figura 1: Estrutura geral dos rinovírus; $1 \mathrm{~A}$ : Estrutura do RV-14 resolvida por cristalografia de raios-X (Rossmann et al., 1985). Visualização do cânion $(\rightarrow$ ); platô do capsômero pentamérico, em forma de estrela e protuberâncias com simetria de 3 eixos ( $\star$ ). 1B: Representação esquemática do capsídeo de RV-16, mostrando a estrutura externa de um protômero (triângulo expandido), destacando o contorno do cânion e o bolsão hidrofóbica alvo de drogas anti-virais. (Kennedy et al., 2012).

de polaridade negativa [RNA(-), tem cauda poli-uridilada (poli-U) (Racaniello, 2013). A poliproteína gerada por tradução do $\mathrm{RNA}(+)$ genômico se compõe de três regiões: P1 (proteínas estruturais), P2 e P3 (proteínas não-estruturais) (Figura 2). A poliproteína sofre clivagens 
proteolíticas co-traducionais, por ação de domínios catalíticos nela contidos, e gera as proteínas virais do capsídeo (VP4, VP2, VP3 e VP1), enzimas proteolíticas envolvidas no processamento da poliproteína (2Apro, 3Cpro, 3CDpro) e na replicação do genoma (2B, 2C, 3AB, 3BVPg, 3CDpro e 3Dpol) (Stanway et al., 1990; Racaniello, 2013).

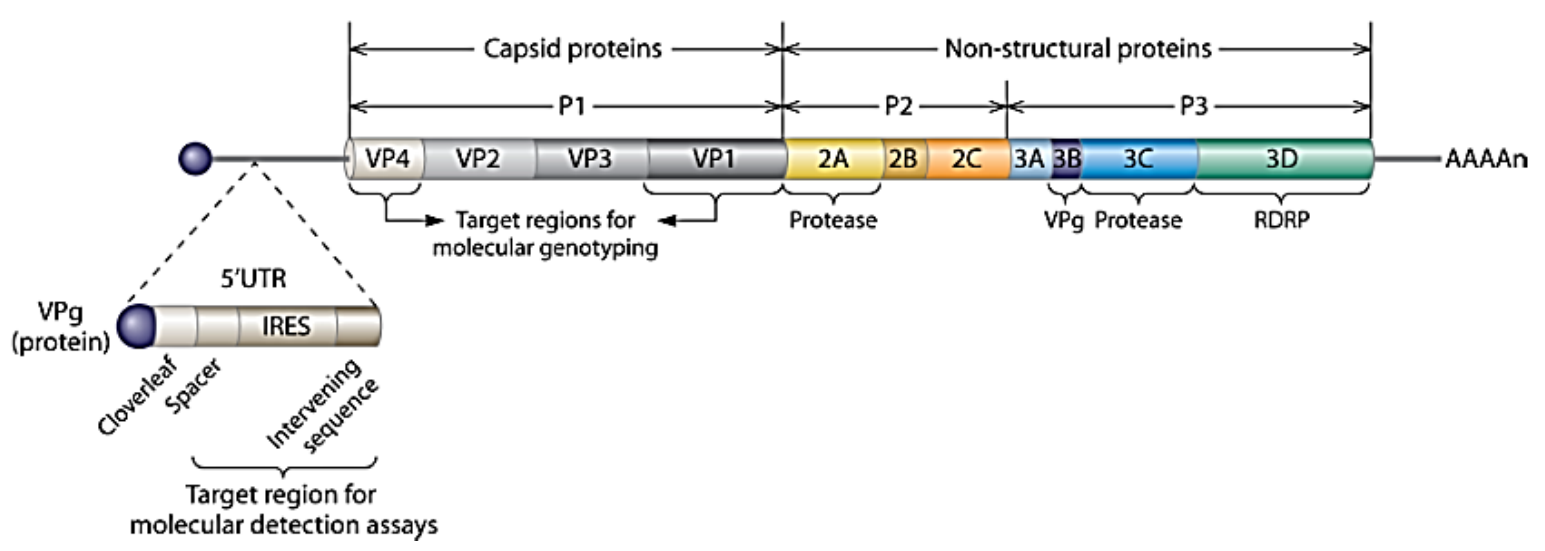

Figura 2: Representação esquemática do genoma de RV e organização da poliproteína viral. As proteínas do capsídeo viral são formadas a partir de P1, enquanto que P2 e P3 originam proteínas virais não-estruturais (proteases, RNA-polimerase RNA-dependente) e VPg. Destaque para o sítio interno de entrada ribossomal - IRES (Jacobs et al., 2013).

\subsection{CICLO REPLICATIVO VIRAL}

A infecção por RV tem início com a ligação do vírus ao seu receptor específico, que pode ser a molécula de adesão intercelular-1 (ICAM-1), receptor de lipoproteína de baixa densidade (LDLR), proteína relacionada ao receptor da lipoproteína de muito baixa densidade (LRP), o próprio receptor da lipoproteína de muito baixa densidade (VLDLR) e precursor 3 relacionado à família das caderinas (CDHR3). Após a translocação do RNA(+) viral para o citoplasma, a replicação do genoma de RV ocorre ancorada em complexos membranosos originários do retículo endoplasmático, denominados fábricas virais. Uma vez que o RNA(+) fica livre no citoplasma, VPg é removida da extremidade 5' e a tradução cap-independente, mediada por IRES, tem início, a fim de gerar a poliproteína. Os domínios da poliproteína com atividade proteolítica $\left(2 \mathrm{~A}^{\mathrm{PRO}} \mathrm{e} 3 \mathrm{C}^{\mathrm{PRO}}\right)$ promovem clivagens seguindo um modelo em “cascata'. Assim que a enzima RNA-polimerase RNA-dependente $\left(3 \mathrm{D}^{\mathrm{pol}}\right)$ surge como fruto dessas clivagens, o RNA (+) é reconhecido através de um RNA 'hairpin' localizado em 2C, e o mesmo serve então de molde para a transcrição de uma fita complementar de RNA (-). Posteriormente, o RNA (-) é utilizado como molde pela mesma $3 \mathrm{D}^{\text {pol }}$ para a replicação do RNA (+) (Paul, 2002). A fase final do ciclo replicativo é a encapsidação do genoma, durante a 
qual há inserção de RNA (+) em capsídeos vazios (partículas B), formando então provirions imaturos, cuja maturação só ocorre após a clivagem de VP0 com formação de VP4 e VP2. Finalmente, a progênie é liberada por lise celular (Figura 4) (Royston \& Tapparel, 2016; Racaniello, 2013).

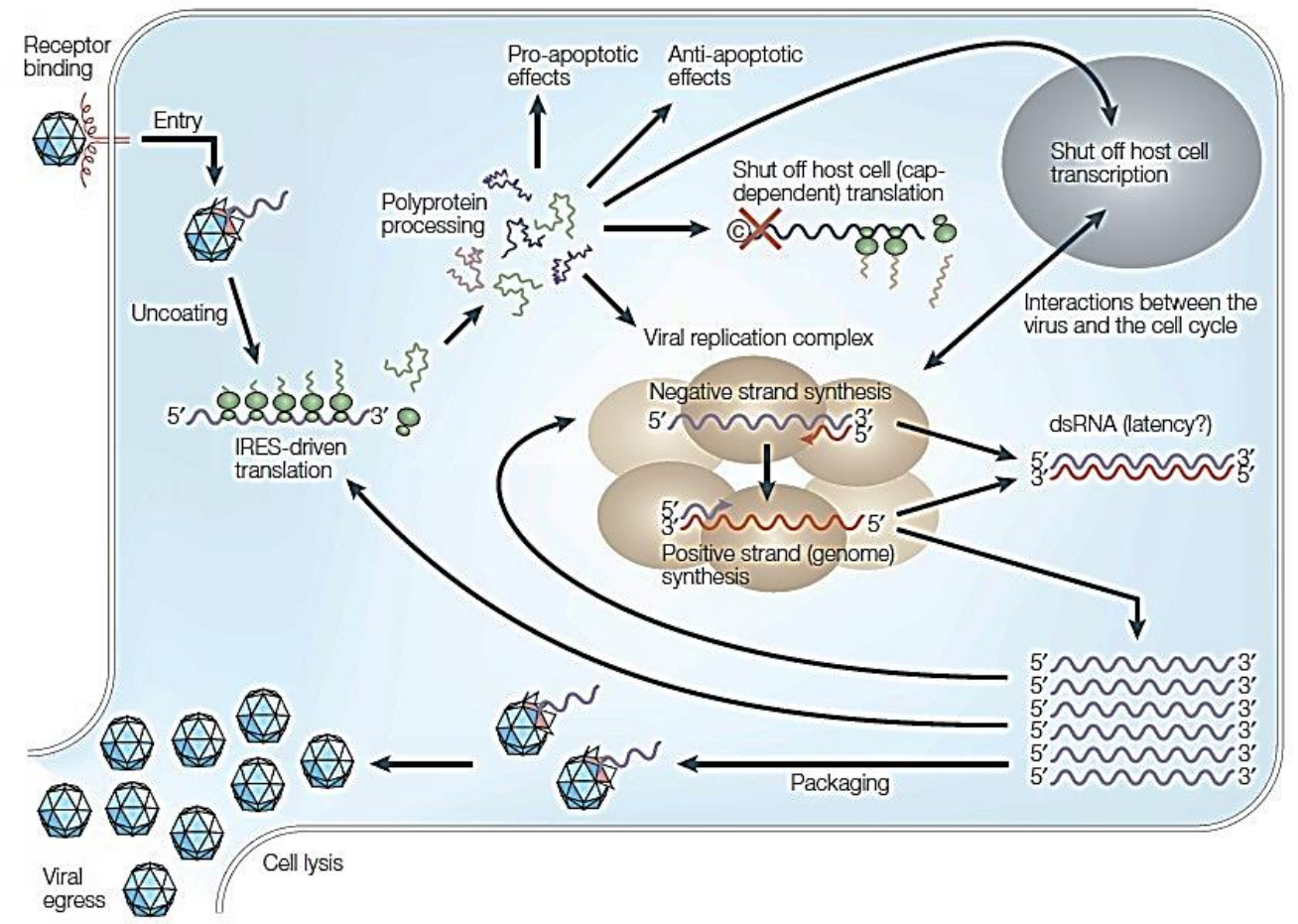

Figura 4. O ciclo replicativo de rinovírus se inicia com a ligação ao receptor específico. Isso provoca mudanças conformacionais no capsídeo, incluindo a perda da proteína VP4 e a liberação do RNA viral. O RNA viral é traduzido em uma poliproteína, que é autoclivada co-traducionalmente por ação de domínios com atividade protease, gerando fragmentos P1, P2 e P3. Estes são posteriormente clivados em fragmentos menores, que constituem as proteínas virais estruturais e não estruturais. Logo que a enzima RNA-polimerase RNA-dependente surge pela clivagem de P3, o RNA viral de polaridade positiva é transcrito em um RNA de polaridade negativa, que servirá de molde para a produção de múltiplas cópias de RNA positivo. Algumas fitas de RNA positivas serão traduzidas em mais proteínas virais. Provírions são formados pela encapsidação de uma cópia de RNA genômico. Posteriormente, a proteína VP0 é clivada em VP4 e VP2. A progênie viral é liberada da célula por lise (Whitton et al., 2005).

\subsection{TRANSMISSÃO E PATOGÊNESE DA INFECÇÃO POR RV}

A transmissão de RV ocorre principalmente por contato manual seguido por autoinoculação em mucosas nasal ou ocular, ou por fômites contaminados por secreção contendo o vírus viável. RV pode permanecer viável em fômites contaminados por até $24 \mathrm{~h}$ 
(Malmstro et al., 2006). Uma vez que o RV atinge a cavidade nasal, a infecção ocorre em praticamente todos os indivíduos susceptíveis expostos, variando em torno de $75-80 \%$ as chances de se desenvolver doença após período de incubação de 1-4 dias (Lessler et al., 2009). A replicação do vírus até o presente é tida como restrita ao epitélio respiratório, essencialmente em células epiteliais sobrejacente a tecidos linfóides na nasofaringe, com posterior disseminação do vírus para o epitélio nasal (Arruda et al., 1991).

A resposta da célula hospedeira à infecção por RV será desencadeada, principalmente, pela participação de receptores do tipo Toll (TLR-3), receptores similares ao gene induzido por ácido retinóico (RIG-I) e sensores do gene associado à diferenciação de melanoma-5 (MDA-5). Tais receptores reconhecem padrões moleculares associados a patógenos (PAMPs), tal como RNA viral de dupla fita (dsRNA), e consequentemente ativam uma cascata de

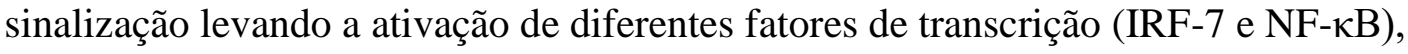
resultando na expressão de interferons do tipo 1 e transcrição de vários genes de citocinas próinflamatórias (IL-1 $\beta$, TNF $\alpha$, IL-6 e IL-8) (Van Cauwenberge et al., 2000; Alexopoulou et al., 2001). Sinergicamente, várias quimiocinas também são expressas e desempenham papel de recrutamento e ativação de diferentes linhagens de células inflamatórias, a saber: CXCL1, CXCL5, CXCL8, CXCL10, CCL5 e CCL20 (Leigh \& Proud, 2011). Recentemente foi observado que a montagem da resposta imunológica em tonsilas humanas infectadas com RV foi associada com padrão Th1, significantemente associada com expressão de IFN- $\gamma$ (Jartti et a., 2014). Os sintomas de infecção por RV consequentes a essa "cytokine storm", são dor de garganta, coriza, obstrução nasal, espirros, prurido nasal, cefaléia, tosse e mal-estar geral. Embora possa haver calafrios, febre não é comum (Arruda et al., 1997).

O RV, diferentemente de outros vírus respiratórios, não causa destruição ou efeito citopático evidente nas células respiratórias epiteliais (Winther et al., 1990). Porém, a infecção por RV pode comprometer a barreira epitelial devido à presença de espécies reativas de oxigênio geradas durante a replicação viral (Unger et al., 2014). Tal fenômeno contribui para a invasão de outros patógenos respiratórios, levando a complicações secundárias (Sajjan et al., 2008).

Além de ser o agente etiológico do "resfriado comum", a infecção por RV pode acarretar obstrução e anormalidades da mucosa da cavidade nasal, seios paranasais, tuba auditiva e ouvido médio (Pitkaranta et al., 1997; Jang et al., 2006; Chantzi et al., 2006 Adicionalmente, o RV pode desencadear quadros de doença pulmonar obstrutiva crônica 
(DPOC), asma e infecções mais graves do trato respiratório inferior em lactentes, idosos e indivíduos imunocomprometidos (Rakes et al., 1999; Heymann et al., 2004; Jain et al., 2015). Em adultos, o RV é responsável por 60-70\% das exacerbações de asma (Bartlett et al., 2009). Mais recentemente, foi demonstrado que a espécie RV-C é importante em infecções do trato respiratório inferior, causando episódios de chiado brônquico e exacerbação de asma, principalmente, em crianças (Lau et al., 2007; McErlean et al., 2007).

A duração média dos sintomas de infecção por RV é de 7 dias, podendo persistir até 14 dias, mas há infecções assintomáticas (Kistler et al., 2007). Em indivíduos asintomáticos a frequencia de detecção de RV por PCR varia de 14\% a 53\% (Jansen et al., 2011; van Benten et al., 2003; Winther et al., 2006). Todavia, é preciso considerar que, além de poder tratar-se de infecções verdadeiras por cepas de baixa virulência, é possível que haja excreção prolongada de vírus persistentes, remanescentes de infecções passadas, cujos mecanismos de persistência ainda são desconhecidos (Kennedy et al., 2012).

Tecidos linfóides tonsilares associados ao trato respiratório superior são reconhecidamente sítios de permanência de agentes virais e bacterianos (Stenfors et al., 2003; Pegtel et al., 2004; Perez et al., 2005; Suvilehto et al., 2006; Bell et al., 2012). ProençaMódena e colaboradores (2012), em estudo feito pelo nosso grupo, em colaboração com a otorrinolaringologia, avaliaram secreções e tecidos de amígdalas e adenóides de indivíduos com hipertrofia adenoamigdaliana, e constataram frequências de $97.5 \%$ de vírus respiratórios nos espécimes estudados, inclusive com elevada frequiência de detecção nos tecidos de adenóides (84\%) e amígdalas (70\%). Naquele estudo, EV e RV foram respectivamente o segundo e terceiro vírus mais frequentes. Os enterovírus não-polio, principalmente Coxsackie, Echovirus e os enterovírus numerados, são agentes com elevado potencial citolítico, e alguns deles podem persistir após a infecção aguda, o que tem sido confirmado em estudos ex vivo com diferentes tecidos (Kandolf et al., 1999; Feuer et al., 2004). O EV, vírus predominantemente de replicação entérica, pode replicar-se no trato respiratório, causando infecções frequentemente subclínicas, mas podendo causar sintomas de resfriado comum. Quando entra pela via gastrointestinal, EV pode estabelecer infecção sistêmica após replicarse inicialmente em tecidos linfoides associados a mucosas (MALT), de onde se espalham para sítios secundários distantes, onde podem causar doenças como meningites, conjuntivites e miocardites, entre outras (Jaidane et al., 2006; Whitton et al., 2005). 
Ainda são obscuros os mecanismos de penetração do RV em tecidos linfo-epiteliais de tonsilas. Arruda e colaboradores (1991) demonstraram em estudo ex vivo a infecção de HRV em células não ciliadas do epitélio das adenóides, provavelmente células "M-like" do tecido analisado. O trajeto do vírus em explantes de tecidos inoculados ex vivo não é bem conhecido. Também não está esclarecido a ocorrência de infecções persistentes ou latentes por RV em tecidos linfoides tonsilares.

\subsection{ANATOMIA DA TONSILA PALATINA E ADENOIDE}

As tonsilas palatinas (amígdalas) e adenóide são órgãos linfóides periféricos que compõem o anel de Waldeyer, logo, são fundamentais na montagem da defesa imunológica contra antígenos ingeridos ou inalados, como bactérias, vírus ou antígenos alimentares (Figura 5) (Perry \& Whyte, 1998). As amígdalas bilaterais estão localizadas no limite da cavidade oral com a orofaringe, entre os arcos palatoglosso e palatofaríngeo, enquanto que a adenoides única fica no teto da nasofaringe (Nave et al., 2001). A região superficial das amígdalas é revestida por um epitélio estratificado pavimentoso não-queratinizado, que se invagina no parênquima tonsilar formando profundas criptas. Enquanto que as adenoides apresentam dobras longitudinais pouco profundas denominadas pregas (Bernstein et al., 1999).

Histologicamente, as tonsilas apresentam uma arquitetura linfóide característica, que inclui um epitélio reticular de superfície, região folicular com centros germinativos primários e secundários, cobertos por zonas do manto e regiões extrafoliculares. As células imunocompetentes que estão localizadas nestas várias regiões da tonsila podem ser macrófagos e células M, células T na zona extrafolicular, células B nos folículos linfóides e células dendríticas específicas no centro germinativo (Nave et al., 2001).

O antígeno é capturado na superfície tonsilar através da membrana apical de células M (microfold), transportado em vesículas até as membranas basolateral celular de onde é exocitado para os espaços intra e sub-epitelial, de onde entra em contato com células $\mathrm{T}$ da zona extrafolicular (Bernstein et al., 1994). A função de transporte de células M não só proporciona uma "amostragem" contínua de antigenos, mas também serve como uma porta de entrada para agentes infecciosos (Gebert, 1997). As células T $\left(\mathrm{CD}^{+}, \mathrm{CD} 8^{+}\right)$, células dendríticas intedigitantes e macrófagos ocupam preferêncialmente as zonas extrafoliculares, mas também podem ser encontradas em centros germinativos e ao longo do epitélio superficial. (Bernstein et al., 1999). As células B estão presentes primariamente no centro germinativo e na zona do manto, mas são encontradas também no epitélio reticular (Schaerli 
et al., 2000). A porcentagem média de células T e B nas tonsilas é $42 \%$ e 52\%, respectivamente. Finalmente, as células dendríticas foliculares residentes no centro germinativo são responsáveis pela apresentação de antígeno para as células B nesta área (Brandtzaeg et al., 1996).

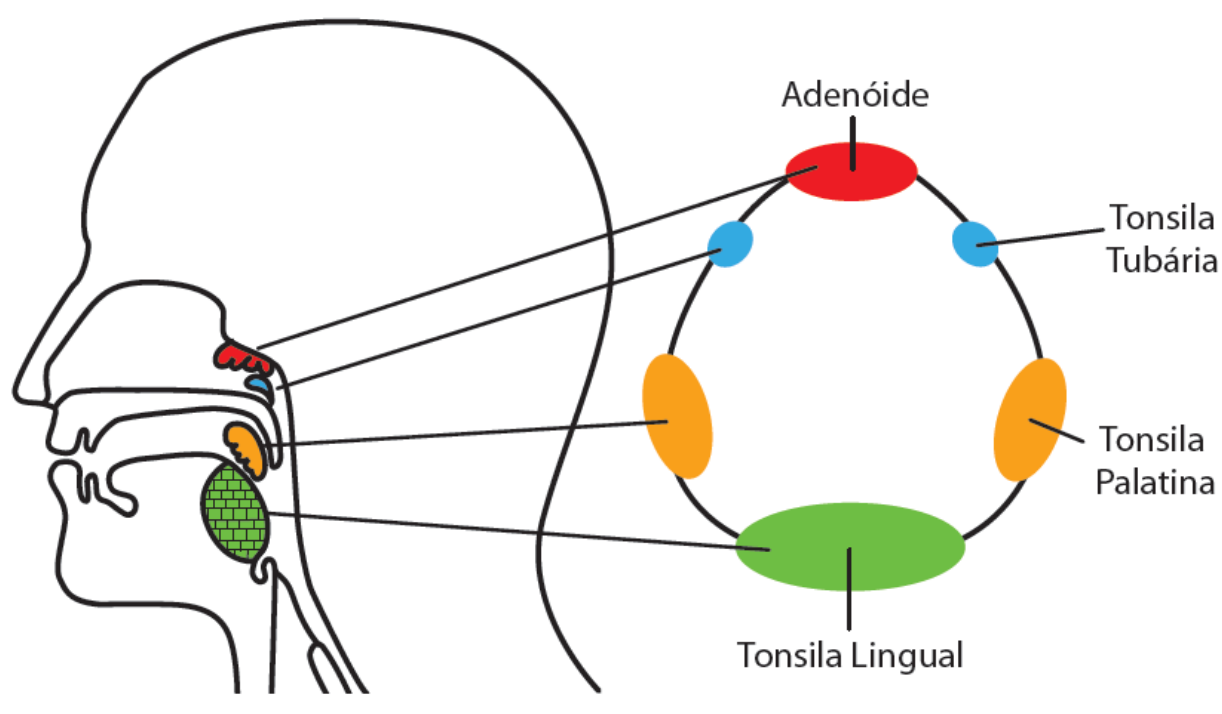

Figura 5. O tecido linfóide faríngeo do anel de Waldeyer é formado pela adenóide, par de tonsilas tubárias, par de tonsilas palatinas (amígdalas) e a tonsila lingual (Figura adaptada de Zhang et al., 2003).

Apesar das tonsilas serem importantes contra antígenos produzindo linfócitos e montando uma resposta imunológica, a tonsilectomia é uma das cirúrgias pediátricas mais amplamente realizados no mundo todo em crianças com tonsilite recorrente ou hipertrofia (hiperplasia) tonsilar crônica. A hipertrofia adenoamigdaliana pode ocasionar obstrução nasal crônica, rinorréia, rinossinusites de repetição, roncos, respiração bucal de suplência, lábios secos, disfunção da tuba auditiva, otite média, voz hiponasalada, apnéia obstrutiva do sono, disfagia, enurese noturna, prejuízo do desempenho escolar, déficit de atenção, alterações do crescimento facial, dificuldade na deglutição e alterações da voz (Kurnatowski et al., 2008). A hipertrofia obstrutiva e as infecções crônicas e recorrentes são as manifestações patológicas mais comuns relacionadas à patologia crônica de adenoides e das amígdalas (Kurnatowski et al., 2008).

O presente estudo teve como objetivo contribuir para o entendimento da infecção de RV em tecidos linfoides de adenoides e amígdalas, longe de estabelecer o RV como o agente etiológico da doença adenoamigdaliana crônica. Até o presente momento, não se sabe a causa etiológica da hipertrofia adenoamigdaliana. 


\subsection{INFECÇÕES PERSISTENTES POR PICORNAVÍRUS}

Os vírus persistem por meio de dois mecanismos fundamentais, a saber: i. Estratégia de replicação viral atenuada, consequentemente causando pouco ou nenhum dano à célula hospedeira; ii. Evasão da resposta imune inata antiviral do hospedeiro (Oldstone, 2009). A resposta imune inata antiviral é desencadeada após reconhecimento de componentes virais: os padrões moleculares associados a patógenos tais como RNA simples fita e RNA dupla fita virais (PAMPs). O reconhecimento ocorre via sensores antivirais do patógeno hospedeiro (PRR), como receptores do tipo Toll (TLR-3), (RIG-I) e MDA-5, o que resulta na ativação de fatores de transcrição de genes de citocinas com propriedades antivirais (Kolumam et al., 2005).

O clearance viral depende de células apresentadoras de antígenos (APCs), tais como células dendríticas (CD), que apresentam peptídeos virais para linfócitos. Segue-se a fase de expansão de célula T efetoras, modulada por citocinas antivirais de atividade citolíticas (IL-2, IFN- $\gamma, T N F)$, culminando na eliminação das células infectadas e aquisição de memória imunológica. Em contrapartida, virus persistentes podem evadir-se do reconhecimento imunológico e manter seus genes em provirus ou epissomos, ou interferir com a montagem da resposta inata antiviral por diferentes estratégias. Como consequência, o vírus garante tempo e espaço para a replicação viral e cronicidade da infecção (Figura 6).

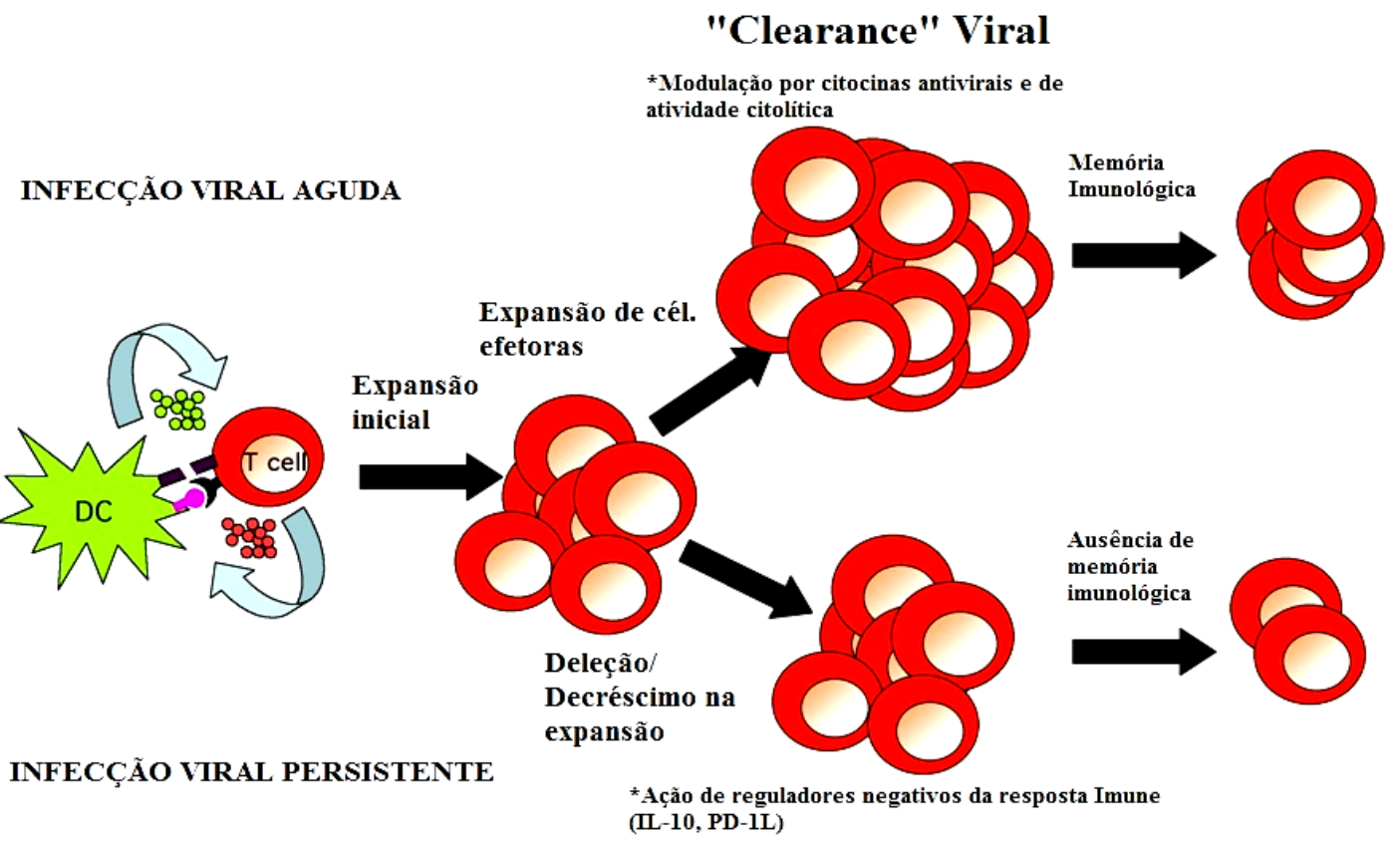

Persistência Viral 
Figura 6: Representação esquemática da montagem da resposta inata do hospedeiro em uma infecção viral aguda ou uma infecção víral persistente/crônica em células imunocompetentes. (Oldstone, 2005).

A maioria dos vírus pertencentes à família Picornaviridae é constituída por agentes que causam infecção lítica. Mesmo assim, vários estudos relatam infecções persistentes por diferentes espécies de picornavírus. É provável que a grande variação genética devido às mutações pontuais no RNA viral, bem como eventos de recombinação, contribui para o surgimento de variantes com virulência atenuada. Tais mutações pontuais foram verificadas, por exemplo, em isolados de poliovírus de pacientes com síndrome pós-polio, localizadas especialmente na região 5' não-codante do RNA viral (Buttinelli et al., 2003).

Mesmo após décadas do quadro inicial de poliomielite, é possível isolar poliovirus relacionado com o re-surgimento de sintomas característicos de síndrome pós-polio (Baj et al., 2015). Modelos in vitro de infecção persistente por poliovírus (PV) já foram descritos, e sabe-se que culturas de células persistentemente infectadas por PV têm baixa expressão de antígenos virais e baixos títulos de produção de progênie viral (PFU/ml $\leq 10^{3}$ ) (ColbereGarapin et al., 1989; Colbere-Garapin et al., 1998; Pelletier et al., 1998).

Em modelos murinos de infecção persistente com coxsackievirus B-3 (CVB3), foi descrito um mecanismo de deleção na extremidade 5' do genoma viral, uma região que desempenha papel fundamental na replicação e tradução. Após 35 dias de infecção, foi detectado o RNA genômico de CVB3 com deleções terminais na extremidade 5', sem obtenção de virions infecciosos nos tecidos dos animais persistentemente infectados (Tracy et al., 2015). Estudo in vitro de infecção persistente de CVB3 em células HeLa sugerem que células em divisão celular têm infecção viral produtiva, enquanto que, células quiescentes (em G0) podem ter infecção latente, promovendo assim a manutenção do genoma viral por longos períodos. Tal achada é relevante para melhor se entender os mecanismos de infecção viral persistente in vivo, uma vez que a maioria das células nos tecidos adultos estão em G0, tais como células do sistema linfoide, por exemplo (Feuer et al., 2004).

Para o vírus causador da febre aftosa (foot-and-mouth disease virus - FMDV), picornavírus responsável por infectar gado bovino, foi descrito persistência do genoma e de proteínas virais em centros germinativos de linfonodos mandibulares, com até 38 dias pósinfecção no animal (Juleff et al., 2008). Embora cardiovírus, outro picornavírus, infectarem principalmente roedores, um novo cardiovírus humano, designado vírus Saffold (SAFV), foi identificado em 2007 (Himeda et al., 2012). Recentemente foi descrito uma infecção 
persistente de SAFV em linhagem de células HeLa, cuja causa provável foi devido à baixa densidade de receptores virais presente na superfície celular (Himeda et al., 2013).

Ainda é obscuro se o principal causador de resfriados comuns pode ou não causar infecções persistentes. Na maioria dos casos, o genoma de RV remanescente de uma infecção recente pode ser detectado por qPCR por até 6 semanas em secreções respiratórias de crianças após a resolução da doença (Jarti et al., 2004; Johnston et al., 1993). Estudos longitudinais envolvendo recém-nascidos com IRA descrevem uma excreção prolongada (maior que 30 dias) do mesmo tipo de RV em 5\% dos casos estudados (Loeffelholz et al., 2014). Em crianças, de 6 a 18 anos de idade, foi observado que a genotipagem dos RV detectados durante crises de asma e oito semanas após a internação dos pacientes, variou em todos os casos, comprovando tratar-se de reinfecção, e não de infecção persistente pelo mesmo tipo de RV. No entanto, ainda que as espécies virais detectadas antes e depois sejam frequentemente diferentes, a presença dos vírus foi associada com maior expressão do gene IP-10 e produção de níveis elevados de citocina IL-10, ambos marcadores de infecção persistente (Wood et al., 2011; Engelmann et al., 2013).

Em indivíduos adultos que receberam transplante de pulmão foi observada infecção persistente por um mesmo tipo de RV, variando de 8 a 15 meses a detecção de genoma e isolamento do vírus a partir de lavados broncoalveolar (Kaiser et al., 2006). Em crianças que receberam transplante de célula-tronco hematopoiética foi descrito infecção persistente por um mesmo genótipo de RV em $1.5 \%$ dos pacientes. A duração da excreção prolongada de RV variou entre 30 a174 dias (mediana de 61 dias) (Piralla et al., 2015). Em ambos os casos citados, a infecção persistente de RV, levando em conta de viroses de RNA são incapazes de causar infecções latentes, acometeu pacientes imunocomprometidos. Anteriormente, um estudo descreveu isolamento de RV em lavados broncoalveolar em 100\% dos pacientes acompanhados, todos eles com doença imunossupressora ou em terapia imunossupressora (Malcolm et al., 2001). 


\section{JUSTIFICATIVA}

O presente trabalho busca esclarecer pontos importantes sobre a infecção de RV em tecidos linfóides do trato respiratório, nos quais se espera justamente que haja combate e eliminação desse frequente patógeno. Além do potencial impacto em patogênese para o hospedeiro cuja tonsila contém vírus viável, essa inusitada persistência, acompanhada de excreção viral contínua ou intermitente, pode ter impacto significativo como fonte de transmissão de RV na comunidade.

\section{OBJETIVOS}

O objetivo do presente trabalho foi explorar os aspectos gerais da infecção viral por RV em tonsilas hipertróficas humanas. Para tal, os seguintes objetivos específicos foram propostos:

-Detectar genoma e senquenciar os tipos observados nos tecidos testados;

-Localizar sítios de replicação viral nas tonsilas naturalmente infectadas;

-Descrever o(s) fenótipo(s) in sito das células infectadas por RV em amígdalas e adenóides;

-Titular partículas virais infecciosas por $\mathrm{TCID}_{50}$ de células tonsilares dissociadas infectadas in vitro com cepas padrão de RV-16;

-Desenvolver modelo ex vivo de explantes de adenóides e amígdalas, a serem infectadas com cepas padrão de RV-16. 


\section{MATERIAIS E METÓDOS}

\subsection{Pacientes e amostras}

No período de maio de 2014 a julho de 2016 foram coletadas amostras de secreções nasofaringe (NSF) e tecidos tonsilares de 104 crianças (61 do sexo masculino) com idades entre 3 e 13 anos (média 7.3 anos e mediana de 6 anos). Todas as crianças tiveram indicação para tonsilectomia devido a hipertrofia tonsilar ou amigdalites recorrentes. Ausência de sintomas de infecção respiratória aguda por pelo menos 1 mês antes do procedimento cirurgico foi utilizada como critério de inclusão, e em todos os casos de tonsilectomia arrolados no presente estudo, os pacientes tiveram a remoção simultânea de amigdalas e adenoide.

Amostras de tecidos de amígdalas e adenoide foram separados no momento da excisão cirúrgica, imediatamente acondicionados em meio de transporte (RPMI, Gibco, Grand Island, USA) suplementado com $10 \%$ de antibiótico e antimicótico (Gibco), e transportadas $4^{\circ} \mathrm{C}$ ao laboratório, com no máximo 4 horas pós-cirurgia. Fragmentos de tecidos de amígdalas e adenoides foram lavados três vezes com solução balanceada de Hanks (BioWhittaker®, Lonza, MD, USA) para remover sangue e debris, e a seguir cortados em fragmentos de aproximadamente $0,5 \mathrm{~cm} \times 0,5 \mathrm{~cm}$, usando instrumentos tratados com dietilpirocarbonato (DEPC) (Sigma, Switzerland) para minimizar contaminação com ribonucleases. As seguintes aliquotas foram obtidas e armazenadas em $-80^{\circ} \mathrm{C}$ para a execução desse estudo: i) Fragmentos macerados em Trizol (Invitrogen, Carlsbad, CA, USA) utilizando homogeneizador automatizado (Tyssue Liser, Quiagen) com uso de esfera metálica, na freqüência de $50 \mathrm{~Hz}$ por 10 minutos, em temperatura ambiente; ii) Fragmentos armazenados em solução preservativa RNAlater® (Invitrogen, Carlsbad, CA, USA); iii) Fragmentos armazenados em meio de congelamento viral (MEM, 20\% SFB e 15\% glicerol); iv) Fragmentos dissociados enzimaticamente com dispase $(0.6 \mathrm{U} / \mathrm{mL})$ e colagenase $(100 \mathrm{U} / \mathrm{mL})($ Gibco, Grand Island, NY, USA) para obtenção de cultura primária de células linfomononucleares (CLMN); v)

Fragmentos preparados para cultivo ex vivo em placas de 24 cavidades contendo insertos Transwell (Corning, NY, USA). vi) Aliquotas de swabs respiratórios armazenados em Trizol (Invitrogen, Carlsbad, CA, USA) e fixados em lâminas para reação de imunofluorescencia indireta. 
Adicionalmente, fragmentos de tecido foram fixados em fixador de Carnoy, composto de $60 \%$ de etanol, 30\% de ácido acético e 10\% de clorofórmio (Merk, Darmstadt, Alemanha) overnight a $4{ }^{\circ} \mathrm{C}$, e em seguida desidratados em série alcóolica (JTBaker, México) por 1 hora cada $(70 \%, 80 \%, 90 \%, 95 \%, 100 \%$ I, II e III), e diafanizados em mistura 1:1 de xilol:etanol por 20 minutos, e submetidos a três trocas de xilol (Synth, Diadema, SP) por 30 minutos cada. A seguir os tecidos foram parafinizados (Merk) em dois banhos de parafina de 2 horas cada, seguidos de inclusão em blocos de parafina. Cortes de $4 \mu \mathrm{m}$ foram preparados em micrótomo Leica e depositados em lâminas carregadas positivamente (Fisher, Pittsburgh, USA).

O foco do presente trabalho foi explorar a infecção por RV em tonsilas humanas, importantes sítios linfoides onde há entrada de RV (Arruda et al., 1991) e onde RV pode ter papel como estímulo à inflamação, sabendo que esses agentes não são a causa de hipertrofia tonsilar nem de amigdalites de repetição. Assim, não foi tentado estabelecer correlações clínicas. Todos os pacientes assinaram termo de consentimento autorizando a coleta de amstras e o estudo foi aprovado pelo comitê de ética do hospital das clínicas (número $10466 / 2008)$.

\subsection{Cepas virais utilizadas no estudo}

Para os ensaios in vitro, foi preparado um estoque viral derinovírus tipo 16 (RV-16) em culturas de células HeLa em suspensão. Brevemente, células HeLa foram cultivadas em suspensão por 48 h sob agitação constante e em seguidainfectadas com RV-16 (MOI=1). A suspensão de HeLa infectada foi incubada em agitação $(90 \mathrm{rpm})$ a $34^{\circ} \mathrm{C}$ por 15 horas. Finalmente, o volume total foi centrifugado a $200 \times \mathrm{g}$ e o sobrenadante armazenado em nitrogênio líquido. Aliquotas do sobrenadante congeladas foram tituladas por ensaio de TCID $_{50}\left(50 \%\right.$ tissue culture infective dose) em HeLa, obtendo-se título de $10^{7,75}$ TCID $50 / \mathrm{ml}$.

\subsection{Detecção do genoma de Enterovirus por PCR em tempo real}

A detecção de genoma de RV e EV foi feita por PCR em tempo real (qPCR) em todas as amígdalas, adenoids e SWABS coletadas. O RNA total foi extraído pelo método de TRIzol $^{\circledR}$ (Life Technologies). Aproximadamente $1 \mu \mathrm{g}$ de RNA foi utilizado na transcrição reversa juntamente com primers hexâmeros randômicos e enzima Multiscribe reverse transcriptase (Applied Biosystems) para a obtenção do DNA complementar (cDNA), que foi utilizado na reação de qPCR. 
Para a detecção do genoma de RV foi padronizado um novo ensaio em tempo real utilizando primers e sonda para a região do gene de 5'NTR. Foi realizado o alinhamento de todas as sequências de RV atualmente disponíveis no GenBank e a região mais conservada do genoma foi utilizada como alvo da reação. Para a detecção do genoma de EV foi utilizada uma metodologia já padronizada em nosso laboratório (Proenca-Modena et al., 2012). O gene endógeno para $\beta$-Actina foi amplificado em todas as reações como controle interno. Todas as reações de qPCR foram realizadas em termociclador Step One Plus Real-Time PCR (Applied Biosystems, Foster City, CA, USA), com primers e sondas específicos (Tabela 1).

A reação de detecção do genoma de RV foi realizada com $3 \mu \mathrm{L}$ of cDNA, $10 \mu \mathrm{M}$ dos primers forward e reverse, $5 \mu \mathrm{M}$ da sonda, $0.15 \mu \mathrm{L}$ de Rox e $7.5 \mu \mathrm{L}$ de master mix TaqMan Sigma-Aldrich, St. Louis, MO, EUA), em volume final de $15 \mu \mathrm{L}$, seguindo os seguintes parâmetros: $95^{\circ} \mathrm{C}$ por 3 minutes, em seguida 45 ciclos de $95^{\circ} \mathrm{C}$ por 10 segundos e $60^{\circ} \mathrm{C}$ por 30 segundos. Para EV, qPCR foi realizada com $3 \mu \mathrm{L}$ de cDNA, $10 \mu \mathrm{M}$ dos primers forward $\mathrm{e}$ reverse, $5 \mu \mathrm{M}$ de sonda, 7,5 $\mu \mathrm{l}$ de master mix de TaqMan (Applied Biosystems), em volume final de $10 \mu \mathrm{L}$, seguindo os seguintes parâmetros: $95^{\circ} \mathrm{C}$ por 10 minutos, em seguida 45 ciclos de $95^{\circ} \mathrm{C}$ por 15 segundos, $55^{\circ} \mathrm{C}$ por 30 segundos e $60^{\circ} \mathrm{C}$ por 1 minuto. A qPCR para $\beta$-Actina foi feita com $3 \mu 1$ de cDNA, $10 \mu \mathrm{M}$ de primers forward e reverse, $5 \mu \mathrm{M}$ de sonda, $5 \mu 1$ de master mix de TaqMan (Applied Biosystems), em volume final de $10 \mu \mathrm{L}$, seguindo os seguintes parâmetros de ciclagem: $95^{\circ} \mathrm{C}$ por 10 minutos, em seguida 45 ciclos de $95^{\circ} \mathrm{C}$ por 15 segundos e $60^{\circ} \mathrm{C}$ por 1 minuto. 
Tabela 1: Primers e sondas utilizados no qPCR

\begin{tabular}{|c|c|c|c|c|}
\hline $\begin{array}{l}\text { Vírus e } \\
\text { controles } \\
\text { internos }\end{array}$ & $\begin{array}{l}\text { Primers } e \\
\text { sonda }\end{array}$ & Sequencia & Alvo & Referência \\
\hline \multirow{3}{*}{ EV } & EV-foward & GCGGAACCGACTACTTTGGG & 5 UTR & \multirow{4}{*}{$\begin{array}{l}\text { Proenca-Modena et al., } \\
2012\end{array}$} \\
\hline & EV-reverse & CTCAATTGTCACCATAAGCAGCC & 5UTR & \\
\hline & EV-sonda & Fam-TCCGTGTTTCCTTTTATTCTTATA-MGB & 5UTR & \\
\hline \multirow{3}{*}{$\mathrm{RV}$} & $\mathrm{RV}$-foward & ACMGTGTYCTAGCCTGCGTGG C & 5 UTR & \\
\hline & $\mathrm{RV}$-reverse & GAAACACGGACACCCAAAGTAGT & 5'UTR & \multirow[t]{2}{*}{$\begin{array}{l}\text { Padronizado no presente } \\
\text { estudo }\end{array}$} \\
\hline & RV-sonda & Fam-TCCTCCGGCCCCTGAAT-BHQ1 & 5UTR & \\
\hline \multirow{3}{*}{$\beta$-actina } & $\begin{array}{l}\beta \text {-actina- } \\
\text { foward }\end{array}$ & CCCAGCCATGTACGTTGCTA & $\beta$-actina & \multirow{3}{*}{$\begin{array}{l}\text { Proenca-Modena et al., } \\
2012\end{array}$} \\
\hline & $\begin{array}{l}\beta \text {-actina } \\
\text { reverse }\end{array}$ & TCACCGGAGTCCATCACGAT & $\beta$-actina & \\
\hline & $\begin{array}{l}\beta \text {-actin- } \\
\text { sonda }\end{array}$ & Fam-ACGCCTCTGGCCGTACCACTGG-Tamra & $\beta$-actina & \\
\hline
\end{tabular}

\subsection{Determinação das espécies de rinovírus presentes em amígdalas e adenoides por sequenciamento.}

Para determinar as espécies de rinovírus presentes nas amostras testadas, o cDNA das amostras positivas por qPCR para RV foram utilizados para obter novos amplicons por qPCR, tendo como alvo a região 5’NTR do genoma de picornavirus.

O amplicon a ser sequenciado foi gerado utilizando 2,5 $\mu \mathrm{L}$ de cDNA, um mix de primers forward (ACMGTGTYCTAGCCTGCGTGG C) e primer reverse $\mathrm{R} 2$ (GAAACACGGACACCCAAAGTAGT) na concentração de $25 \mu \mathrm{M}$, com enzima de alta fidelidade ("Phusion High Fidelity DNA Polimerase", Finnzymes), com volume final de 25 $\mu \mathrm{L}$ (Lee et al., 2007), seguindo a mesma ciclagem anterior Os produtos de PCR foram 
tratados com ExoSAP (Affymetrix, USA) e incubados a $37^{\circ} \mathrm{C}$ por 25 minutos e depois a $90^{\circ} \mathrm{C}$ por 15 minutos.

A reação de seqüenciamento foi realizada com $3 \mu \mathrm{L}$ do produto de PCR utilizando $2 \mu \mathrm{L}$ de BigDye (Applied Biosystem, Foster City, CA, USA), 10 pmoles do primer reverse e $3 \mu \mathrm{L}$ de Buffer (Applied Biosystem), em volume final de $20 \mu \mathrm{L}$, em seqüenciador ABI7500 (Applied Biosystem).

\subsection{Imunohistoquímica para detecção da proteína estrutural de capsídeo de rinovírus.}

Os ensaios de imunohistoquímica (IHQ) foram realizados de acordo com protocolo já estabelecido em nosso laboratório (Santos et al., 2012). Cortes de amígdalas e adenoides foram desparafinizadas em 3 banhos de xilol (Synth, Diadema, SP) por 5 minutos cada, e hidratados por incubações sequenciais de 5 minutos em concentrações decrescentes de etanol (JTBacker, Mexico) (100\%, 90\%, 80\%, 70\% e 50\%).

Os cortes foram submetidos a desmascaramento antigênico em 10mM de tampão citrato pH 6.0 (Sigma, St Louis, MO, USA) com aquecimento por 4 minutos em forno de microondas (Brastemp, Brasil) na potência máxima, e 16 minutos em potência equivalente a $10 \%$ da máxima. Em seguida, os cortes foram incubados com $4 \%$ de $\mathrm{H}_{2} \mathrm{O}_{2}$ (Synth) por 30 minutos, lavados com PBS (Gibco, Grand Island, NY, USA), bloqueados por 30 minutos em PBS com 0,01\% de BSA (Gibco) e 3\% de soro de cavalo (Gibco), e então incubadas com dois tipos diferentes de anticorpo monoclonal de camundondo, separadamente em duplicatas: antiVP2 (mabR16-7, QED Bioscience, San Diego, CA) e anti-VP-1 (mab8430, Millipore, Temecula, CA, USA), ambos diluídos a 1:1000 em PBS/BSA e 0,1\% de triton-X100 (Sigma), pH 7.4, por $1 \mathrm{~h}$ à temperatura ambiente. Seguiu-se incubação com anticorpo de cavalo anticamundongo biotinilado (Vector, Burlingame, CA) diluído 1:2000 em PBS pH 7.4, por 30 minutos à temperatura ambiente. A detecção do anticorpo biotinilado foi feita com estreptavidina conjugada com peroxidase, diluída 1:300 (Sigma) por 20 minutos em temperatura ambiente, usando como substrato da peroxidase o kit NovaRED (Vector), seguindo as orientações do fabricante. A contracoloração foi feita com hematoxilina de Harry (Vector), e os cortes foram desidratados por incubações de 3 minutos cada em concentrações crescentes de etanol e a seguir em xilol (etanol a 50\%, 70\%, 80\%, 90\%, 100\%, xilol:etanol 1:1 e xilol 100\%), e montados com Entellan (Merck, Darmstadt, GE). 
Coágulos parafinados de suspensão de células HeLa infectadas por RV-16 e RV-1A e não infectadas foram utilizados como controles positivos e negativos, respectivamente. Para esta preparação, seis horas após infecção com CoxB5 monocamadas de células Hela foram removidas, lavadas 2 vezes com PBS (Gibco) e centrifugadas a $180 \times$ g por 10 minutos. Após descarte do sobrenadante a pellet de células foi ressuspendido em $100 \mu 1$ de plasma humano, ao qual foram adicionados $20 \mu 1$ de trombina (Diagnostica Stago, Gennevilliers, France), seguindo-se incubação em geladeira por uma hora para formação do coágulo, e fixação em 4\% de paraformaldeído (Electron Microscopy Sciences, Hatfield, PA) em PBS pH=7,2 por 12 horas. Após a fixação os coágulos foram desidratados em concentrações crescentes de etanol (JTBaker) (50\%, 70\%, 80\%, 90\%, 95\% e 100\%), imersos em três banhos de xilol (JTBaker) e em seguida incluídos em parafina (Merk). Preparação idêntica foi feita com células HeLa não infectadas como controle negativo.

\subsection{Imunohistoquímica sequencial (SIMPLE) para proteínas virais e para marcadores de células linfomononucleares de tonsilas.}

Cortes de tecido positivos para os rinovírus foram investigados por IHQ seriada pelo método SIMPLE (Sequential Immunoperoxidase Labeling and Erasing Method). Utilizamos SIMPLE para identificar tipos celulares co-localizados com marcações positivas para a proteínas estrutural viral (Glass et al., 2009). Um mesmo corte de tecido foi testado sequencialmente com marcadores apropriados anti-CD4 (AB 133616, Abcam), anti-CD8 (AB 4055, Abcam), anti-CD20 (AB 27093, Abcam), anti-CD11c (AB-52632, Abcam) após marcação inicial positiva para a proteína estrutural viral, intercalando-se etapa de remoção do sinal entre cada uma das testagens para sucessivos marcadores. Resumidamente, após realização da IHQ como descrito na sessão acima, a marcação foi revelada com cromógeno AEC (Vector Laboratories), por no máximo 30 min ou até a formação de coloração vermelha, e as imagens foram transformadas em arquivo digital no microscópi Leica ScanScope (Leica Microsystems, Wetzlar, Germany). A seguir, os tecidos marcados foram desidratados em série alcóolica até o desaparecimento do sinal positivo. Para eluição dos anticorpos, as lâminas foram incubadas em $0.15 \mathrm{mM} \mathrm{KMnO} / / 0.01 \mathrm{M} \mathrm{H}_{2} \mathrm{SO}_{4}$ por 2 min a temperatura ambiente, e lavadas imediatamente em água destilada. Os tecidos foram remarcados com outro anticorpo de interesse, e a contracoloração feita com hematoxilina de Harry (Vector) foi realizada somente após a última marcação. 


\subsection{Hibridação in situ (ISH) para detecção do antigenoma de rinovírus com sonda de} LNA.

Para documentar a replicação ativa de HRV foi realizada a hibridação in situ com sonda para o antigenoma de RV, intermediário replicativo viral. Utilizamos como sonda um oligonucleotídeo de Locked Nucleic Acid (LNA), marcado com digoxigenina nas extremidades 5' e 3' (sonda HRVTS3 forward [5'DigN/GGA+YGG+RACC+RACTACTTTGG+RTGTCC/DigN3'] Exiqon, França), seguindo protocolos previamente publicados, e já padronizados em nosso laboratório (Arruda et al., 1995; Jorgensen et al., 2010). As sondas HRVTS3 foram feitas com digoxigenina, permitindo assim revelação mediante anticorpo anti-digoxigenina feito em cabra e marcado com DyLight@ 594 (DI-7594) (Vector), e permitiram usar temperatura de 'melting' de até $87^{\circ} \mathrm{C}$, garantindo assim a alta especificidade dos híbridos. Foram utilizadas sondas para RNAm de $\beta$-actina como controle positivo endógeno (5DigN/CTCATTGTAGAAGGTGTGGTGCCA/3DigN), e sondas scrambled como controle negativo (5DigN/ACACGCTTCCATCTGGC GCT/3DigN). Brevemente, os tecidos foram desparafinizados em três banhos de xilol (Synth) por 5 minutos cada, e re-hidratados em banhos de etanol (JTBaker) em concentrações decrescentes de 100\%, 96\% e 70\%, cada um feito em duas mudanças, a inicial por 1 minuto e mais uma adicional por 5 minutos. Os cortes foram submetidos a desmascaramento antigênico em 10mM de tampão citrato pH 6.0 (Sigma, St Louis, MO, USA) com aquecimento por 4 minutos em forno de microondas (Brastemp, Brasil) na potência máxima, e 16 minutos em potência equivalente a $10 \%$ da máxima. A seguir, os cortes foram lavados três vezes por 5 minutos em PBS e incubados com solução de pré-hibridação (SSC 4X com BSA $10 \mathrm{mg} / \mathrm{mL}$ ) por 20 minuto a $55^{\circ} \mathrm{C}$. A solução de hibridação (SSC $4 \mathrm{X}$ com $10 \%$ dextran sulfato) com $2,5 \mu \mathrm{M}$ de sonda foi adicionada em seguida, sem lavagens prévias, e incubação ocorreu a $55^{\circ} \mathrm{C}$ por 1 hora.

As lâminas foram lavadas em $4 \mathrm{X} \mathrm{SSC}$, duas vezes durante 5 minutos a $50^{\circ} \mathrm{C}$, lavadas em $2 \mathrm{X} \mathrm{SSC}$, duas vezes durante 5 minutos cada, a $50^{\circ} \mathrm{C}$, seguido de lavagem em $1 \mathrm{X}$ SSC por 5 minutos à temperatura ambiente. A seguir foram incubadas overnight com solução de bloqueio (PBS pH=7,2, Tween a $0,1 \%$, BSA a $1 \%$ e soro de cabra a $2 \%$ ), com anticorpo primário anti-digoxigenina (Goat anti-Digoxigenin/digoxin, Vector, MB-7000) diluído 1:500 em PBS 1X. No dia seguinte, as lâminas foram lavadas três vezes por 3 minutos cada com PBS 1X, e incubadas com anticorpo secundário DyLight@594 anti-digoxigenina/digoxina (DI-7594, Vector Laboratories, CA, USA) diluído 1:1000 em PBS/BSA/Triton, por 1 hora à 
temperatura ambiente. Após três lavagens com PBS 1X, adicionou-se as lâminas solução de montagem ProLong ${ }^{\circledR}$ Gold Antifade Reagent, que contendo DAPI (Molecular Probes, Thermo Fischer Scientific, Carlsbad, CA, USA). As laminas foram analisadas em microscópio confocal TCS SP5 (Leica Microsystems, Milton Keynes, Bucks, UK).

\subsection{Isolamento de cultivo de CLMN derivadas de tonsilas.}

CLMN foram obtidos exclusivamente de tonsilas (amigdalas e adenoides) que apresentaram resultados de detecção de genoma de RV e EV negativo por qPCR. A dispersão dos tecidos linfoides foi realizada com a utilização de enzimas proteolíticas: Colagenase tipo I (Gibco) e Dispase (Gibco). Inicialmente, restos celulares e coágulos sanguíneos foram removidos das tonsilas por lavagem sucessivas com solução salina balanceada de Hanks (HBSS) e fragmentos de 4 mm foram obtidos com utilização de lâminas cirúrgicas estéreis, priorizando o parênquima tecidual. Os fragmentos de amigdalas ou adenoides foram lavados três vezes em PBS 1X (sem cálcio e magnésio), antes da adição da solução de dissociação celular. A desagregação tecidual foi otimizada em solução com dispase $(0.6 \mathrm{U} / \mathrm{mL})$ e colagenase tipo I (100 U/mL). A solução de dissociação contendo os fragmentos de tecidos foi cuidadosamente adicionada à garrafa Spinner Flask (volume total de $10 \mathrm{~mL}$ ), seguida de incubação a $37^{\circ} \mathrm{C}$ e $5 \%$ de $\mathrm{CO}_{2}$, por uma hora em agitação leve e constante. Após esse período, a separação das células dissociadas foi completada com o auxílio de membranas de nylon Cell Strainer estéreis e com poros de $100 \mu \mathrm{m}$ (Spllifesciences). As células em suspensão foram centrifugadas a 200 x g, por 10 minutos, e suspendias em meio RPMI-1640 com 10\% SFB. A viabilidade celular foi determinada em câmera de Neubauer, com azul de trypan. A purificação das células linfomonucleares foi realizada por meio de gradiente de Ficoll-Paque PLUS (Amersham Bioscience). A solução contendo a dispersão celular foi diluída em PBS, na proporção de 1:1. Em seguida, foi adicionada cuidadosamente sobre a solução de Ficoll-Paque PLUS, na proporção de 2:1 e todo o sistema foi centrifugado 1.500 rpm, por 15 minutos à temperatura ambiente sem desaceleração.

Após a separação das células linfomononucleares, a camada intermediária foi cuidadosamente aliquotada em um novo tubo para ser lavada três vezes com PBS 1X a fim de retirar Ficoll-Paque PLUS residuais. Para padronização de cultura primárias de células dendríticas a partir de CLMNs dispersas, foi realizado inicialmente uma purificação de monócitos utilizando um gradiente diferencial de Ficoll-Paque PLUS, seguida de tratamento com IL-4 e GM-CSF. Brevemente, a partir de uma centrifugação com gradiente de Ficoll- 
Paque $P L U S^{\circledR}$, foi realizada uma nova centrifugação utilizando gradiente de Percoll $^{\circledR}$ com densidade ajustada para $1.064 \mathrm{~g} / \mathrm{ml}$ por meio de diluição com PBS 1X (Lehner \& Holter, 2002). Em seguida, após três lavagens em PBS $1 \mathrm{X}$ para retirada de traços de Percoll $^{\circledR}$, os monócitos foram cultivados em meio RPMI 1640, $2 \mathrm{mM}$ glutamine, 1\% de antibióticos/antimicóticos, $10 \% \mathrm{SFB}$, suplementados com fator de crescimento recombinante humano GM-CSF (800 U/ml, Peprotech, NJ, EUA) e citocina reconbinante humana IL-4 (1000 U/ml, Peprotech, NJ, EUA). A cada dois dias meio fresco era adicionado à cultura, com total de 5 dias de cultivo antes da inoculação com os estoques virais (Chapuis et al., 1997).

\subsection{Cultura de CLMN com vírus}

As culturas primárias de CLMN foram expostas a cepas de RV-16 na proporção de um vírus para cada uma célula (MOI = 1). Brevemente, as infecções in vitro das células linfomononucleares purificadas foram realizadas em meio de cultivo McCoy`s suplementado com $2 \%$ de SFB e cloreto de magnésio $(30 \mathrm{mM})$, considerada MOI igual a 1. Culturas de HeLa foram simultaneamente infectadas para funcionar como controle de infectividade viral, por vizualização de CPE. Duas horas após a inoculação com as cepas virais, as células foram lavadas em PBS três vezes para remoção de partículas virais não aderidas. Lâminas de controle negativo das células linfomononucleares foram preparadas em cada ensaio de infecção.

\subsection{Titulação de $R V$ em células linfocitárias infectadas.}

A quantificação de RV produzido em células linfoides infectadas in vitro com RV-16, foram realizados ensaios de titulação viral por TCID 50 . Brevemente, células HeLa-I foram adicionadas em placas de 96 cavidades a fim de formar uma monocamada com $70 \%$ de confluência. As células linfoides infectadas e o sobrenadante foram separados após centrifugação $\left(200 \mathrm{~g} \mathrm{e} 4^{\circ} \mathrm{C}\right)$, e em seguida as suspensões foram tituladas, após diluições seriadas em meio de cultura McCoy $2 \%$ SFB com adição de cloreto de magnésio $30 \mathrm{mM}$, nas placas de cultura de $\mathrm{HeLa}$ a $33^{\circ} \mathrm{C}$ por três dias.

\subsection{Reação de Imunofluorescência Indireta (RIFI)}

As lâminas utilizadas para RIFI foram fixadas em acetona a $4^{\circ} \mathrm{C}$ por cinco minutos e armazenadas em $-20^{\circ} \mathrm{C}$ até a realização do ensaio. Inicialmente, as lâminas foram bloqueadas por 30 minutos em PBS/BSA (1\%)/Triton (0.01\%) com 5\% de soro, e então incubadas com anticorpo monoclonal primário em PBS/BSA $1 \%$ com Triton $0.1 \%$, na diluição padronizada, 
pH 7.4, por $1 \mathrm{~h}$ à temperatura ambiente. Após três lavagens com PBS 1X, seguiu-se incubação com anticorpo secundário conjugado com o fluoroforo, diluído em PBS/BSA (1\%) com Triton $(0.01 \%)$, pH 7.4, por 30 minutos à temperatura ambiente, e novas lavagens com PBS em câmara escura. Finalmente, as lâminas foram incubadas com solução de marcação nuclear DAPI $(1 \mu \mathrm{g} / \mathrm{mL})$ por cinco minutos à temperatura ambiente com três lavagens subseqüentes em PBS 1X. Os seguintes anticorpos monoclonais foram utilizados como anticorpos primários: anti-VP2 (mabR16-7, QED Bioscience, San Diego, CA) e anti-VP-1 (mab8430, Millipore, Temecula, CA, USA), ambos feitos em camundongos e diluídos a 1:300; anti-dsRNA, que reconhece fitas duplas de RNA (mAb J2-1511, Scicons); anti-CD3 (Abcam, ab-5690), anti-CD4 (Abcam, ab-133616), anti-CD8 (Abcam, ab-4055), anti-CD11c (Abcam, ab-52632), anti-CD20 (Abcam, ab-27093), anti-CD33 (Abcam, ab-186598), antiCD56 (Abcam, ab-758113), todos feitos em coelho e na diluição de 1:1000. Os anticorpos segundários utilizados foram: anti-camundongo conjugado com FITC feito em cabra (Merck Millipore mAb AP124F, diluíção 1:100) e anti-coelho conjugado com Alexa-594 feito em cabra (Abcam ab-150080, diluíção 1:1000).

\subsection{Explantes de tonsilas e inoculação com RV-16}

Durante o processamento de amigdalas e adenoides, restos de tecidos e coágulos sanguíneos foram removidos por várias lavagens com solução salina balanceada de Hanks (HBSS), e fragmentos com até $5 \mathrm{~mm}^{3}$ foram obtidos a partir da superfície epitelial do tecido, priorizando cortes orientados para criptas das tonsilas palatinas, e evitando a base de adesão à fossa tonsilar. Para adesão dos fragmentos ao frasco, o explante foi mantido por 5 minutos sobre os inserts à temperatura ambiente e em seguida adicionou-se meio RPMI 1640,

suplementado com $10 \%$ de SFB. Os tecidos foram mantidos em interface líquido-ar utilizando uso de placas transwell de 12 cavidades com inserts permeáveis de poliéster com poros de 0.4 $\mu \mathrm{m}$ (Corning, Lowell, MA, USA), e tratados com fator de crescimento semelhante à insulina 10ng/ml (IGF) e de fator de crescimento epidérmico recombinante humano 60ng/ml (EGF) (Gibco, Carlsbad, CA, USA) (Dills et al., 1984).

As culturas foram incubadas a $37^{\circ} \mathrm{C}$ em $5 \%$ de $\mathrm{CO}_{2}$, com troca de meio a cada três dias. Os explantes, tanto de amígdalas quanto de adenoides, foram mantidos por até 14 dias em cultivo, sem perda da viabilidade, com formação de extenso crescimento de outgrowth de epitélio e de fibroblastos. Após 7 dias de cultura dos explants, constatado o outgrowth epitelial e ausência de contaminação bacteriana, os fragmentos foram lavados três vezes em 
PBS antes de realizar a inoculação com RV-16. A inoculação foi realizada com adição $5 \mu \mathrm{L}$ de HRV-16 a 10 ${ }^{7,25}$ TCID $_{50} / \mathrm{mL}$, em meio de cultivo McCoy`s suplementado com $2 \%$ de SFB e cloreto de magnésio 30mM, no ápice do explante. Em paralelo a cada experimento, controles negativos adequados foram cultivados. Após 24 horas, o fragmento inoculado foi lavado três vezes em PBS e re-incubado a $33^{\circ} \mathrm{C}$ em atmosfera com $5 \%$ de $\mathrm{CO}_{2}$, por mais três dias. Em seguida o tecido foi fixado, desidratado, e incluído em parafina.

\subsection{Isolamento de RV}

O isolamento de RV foi tentado em células de fibroblasto WI-38 e células HeLa-I, baseados em procedimentos publicados (Arruda et al., 1996). Fragmentos de tecido tonsilar foram dispersados através de homogeinizador automatizado Tissue Lyser LT (Qiagen). Em seguida, a suspensão cellular foi snap-freeze em N2(liq) e descongelado. As amostras foram clarificadas por centrifugação $\left(10 \mathrm{~min} / 1000 \mathrm{~g} / 4^{\circ} \mathrm{C}\right)$, e o sobrenadante foi filtrado em poros de $0.22 \mu \mathrm{m}$ para minimizer contaminação bacteriana. Os sobrenadantes foram inoculados em monocamadas de células WI-38 e células HeLa em placas de cultura de 24 cavidades, com incubação a $33^{\circ} \mathrm{C}$ em atmosfera com $5 \% \mathrm{CO} 2 . \mathrm{O}$ meio de manutenção utilizado nos isolamentos foi McCoy's (Sigma-Aldrich) com 2\% FBS, $30 \mathrm{mM} \mathrm{MgCl2,} 1 \%$ de antibióticos/antimicóticos. As células foram monitoradas diariamente até vizualização de efeito citopático (CPE). Foram realizadas até 3 passagens cegas das células até vizualização de CPE. Os isolados foram confirmados por RIFI e sequenciamento da região 5'NTR. 


\section{RESULTADOS}

\subsection{Frequência de detecção de genoma de RV e EV por qPCR}

Considerando-se adenoides, amigdalas e secreções respiratórias analisadas, a frequência total de detecção de genoma de pelo menos um dos picornavírus testados foi de 84.6\% (88/104). Portanto em apenas 16 pacientes não foi detectado genoma de RV ou EV. Observamos que a frequência de detecção viral variou de acordo com o sítio analisado: na adenoide as frequências de detecção de RV e EV foram $42.3 \%$ (44/104) e 58\% (60/104) respectivamente; nas amígdalas as frequencias de detecção de RV e EV foram $21.1 \%$ (22/104) e 55\% (57/104) respectivamente; nos swabs as frequências de detecção de RV e EV foram 21.1\% (22/104) e 44\% (46/104) respectivamente (Figura 7).

As frequências de co-detecção de RV e EV em adenoides, amígdalas e swabs foram $25.9 \%$ (27/104), $14.4 \%(15 / 104)$ e $6.7 \%$ (7/104).

(a)

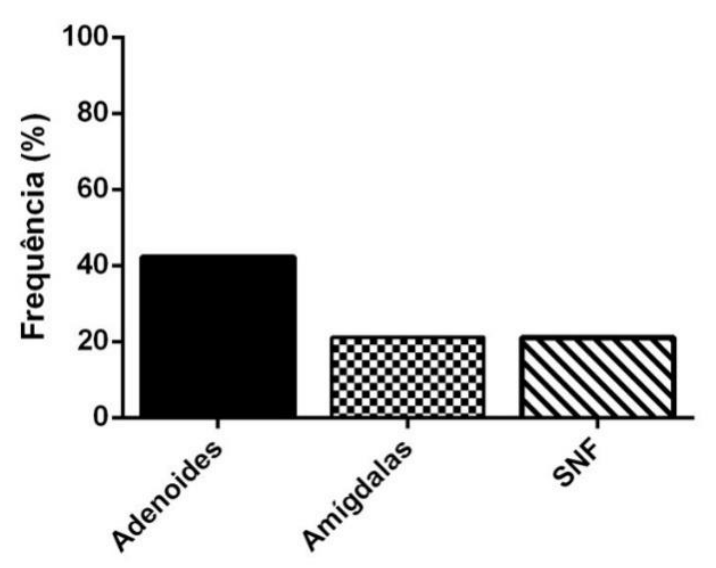

(b)

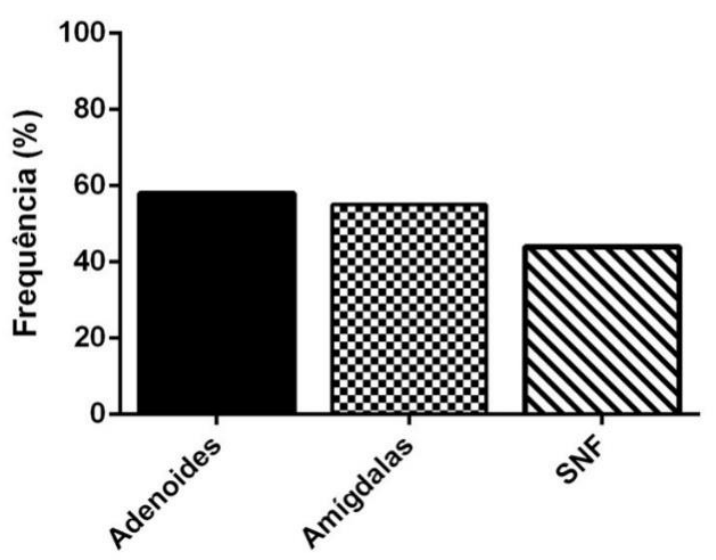

Figura 7. Frequências de detecção de genoma de RV (a) e EV (b) por qPCR em adenoides, amígdalas e SNF.

\subsection{Localização de proteínas virais e determinação de fenótipos das células susceptíveis} em adenoides e amígdalas naturalmente infectadas por $R V$.

Os ensaios de IHQ foram realizados utilizando 6 amígdalas e 15 adenoides de 17 pacientes cujos tecidos eram disponíveis, todos eles positivos por qPCR exclusivamente para $\mathrm{RV}$. Selecionamos tecidos de pacientes positivos apenas para RV com o intuito de minimizar resultados controversos devido à possibilidade de reação cruzadas do anticorpo anti-VP-1 
(mab8430, Millipore, Temecula, CA, USA) com cepas de EV. Os resultados revelaram positividade em 5/6 amígdalas e em 100\% das adenoides testadas por IHQ. Em amígdalas, foi possível observar positividade ao longo de epitélio estratificado pavimentoso não queratinizado de criptas. Em amígdalas de 4 pacientes, houve marcação para VP1 focalmente localizada em células do centro germinativo de folículos linfoides, e em todos os corte de amígdalas houve marcações dispersas na região extra-folicular, logo abaixo do epitélio superficial (Figura $8 \boldsymbol{c} \boldsymbol{e} 8 \boldsymbol{8}$ ). Em adenoides, marcação intensa foi detectada em células epiteliais ciliadas, bem como em células do tecido linfoide, dentro e fora de folículos (Figura $\boldsymbol{8 d}, \boldsymbol{8 e}, \boldsymbol{8 f})$. Em todas as reações de IHQ foram incluídos controles positivos e negativos adequados (Figura $8 \boldsymbol{a} \boldsymbol{e} 8 \boldsymbol{b}$ ).

Os resultados de IHQ sequencial pela estratégia de SIMPLE, para antígeno viral e para marcadores linfocitários, permitiram determinar os tipos de células expressavam a proteína viral VP2, específica de RV, em tecidos de 2 adenoides naturalmente infectadas. Foram detectadas células CD4+ e outras CD20+ com co-marcação para proteína VP2 de RV (Figura 9). Não houve marcação para VP2 em células CD8+ nem CD11 ${ }^{+}$ (monócitos/macrófagos/células dendríticas imaturas). 

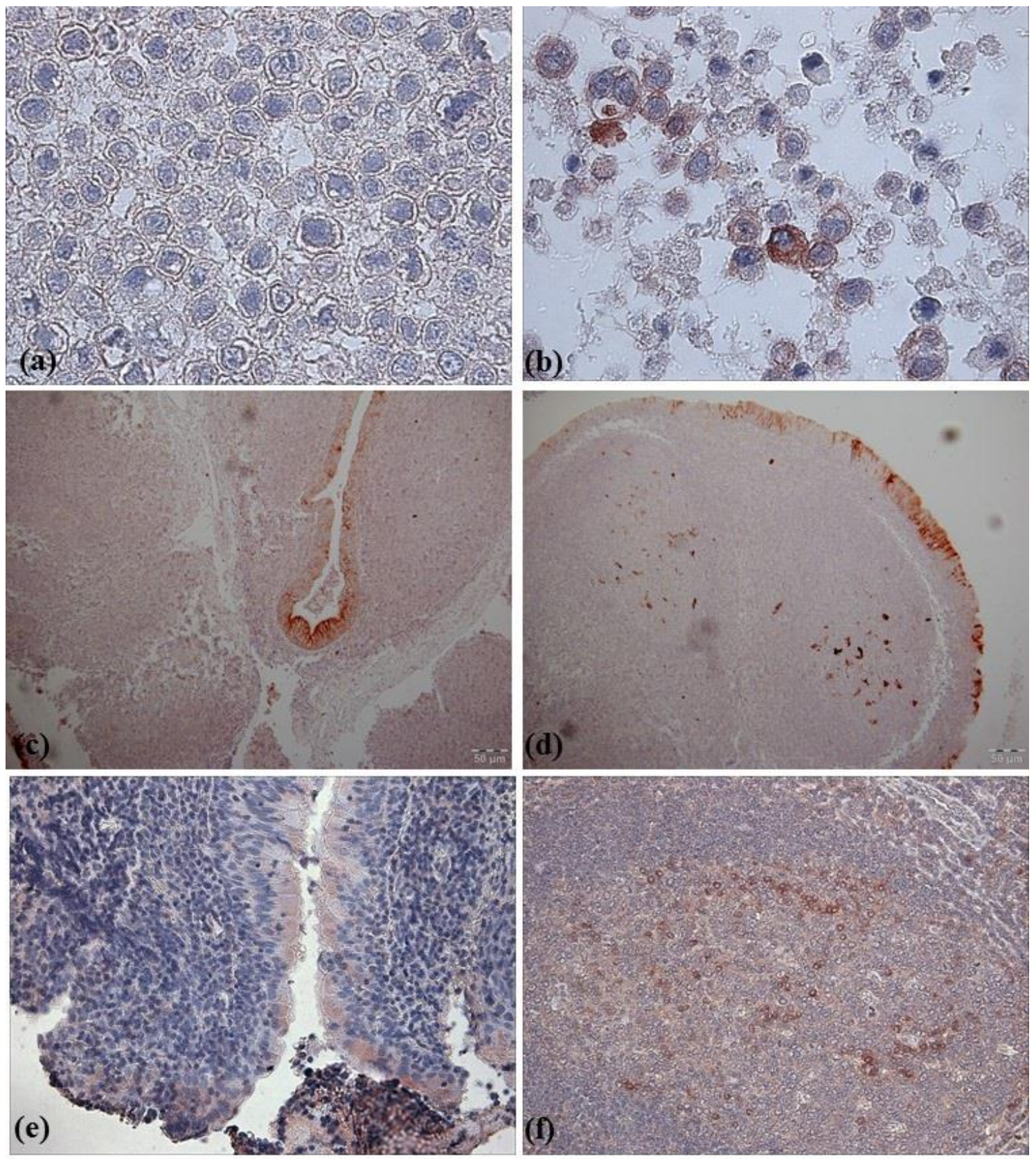

Figura 8. Imunohistoquímica para proteína de capsídeo (VP1) de rinovírus. (a) Controle negativo feito em coágulo de células Hela não infectadas (1000x); (b) controle positivo feito em coágulo de células Hela infectadas com RV-16 (1000x); (c) marcação no epitélio de criptas de amígdala (100x); (d) marcação no interior de folículos linfoides e, simultaneamento, no epitélio pseudo-estratificado na superfícia de amígdala (100x); (e) marcação no epitélio ciliado de adenoide (200x); em (f) marcação difusa para VP1 no interior de centro germinativo de folículos linfoides de adenoide (200x).

Contracoloração com hematoxilina de Harris. 

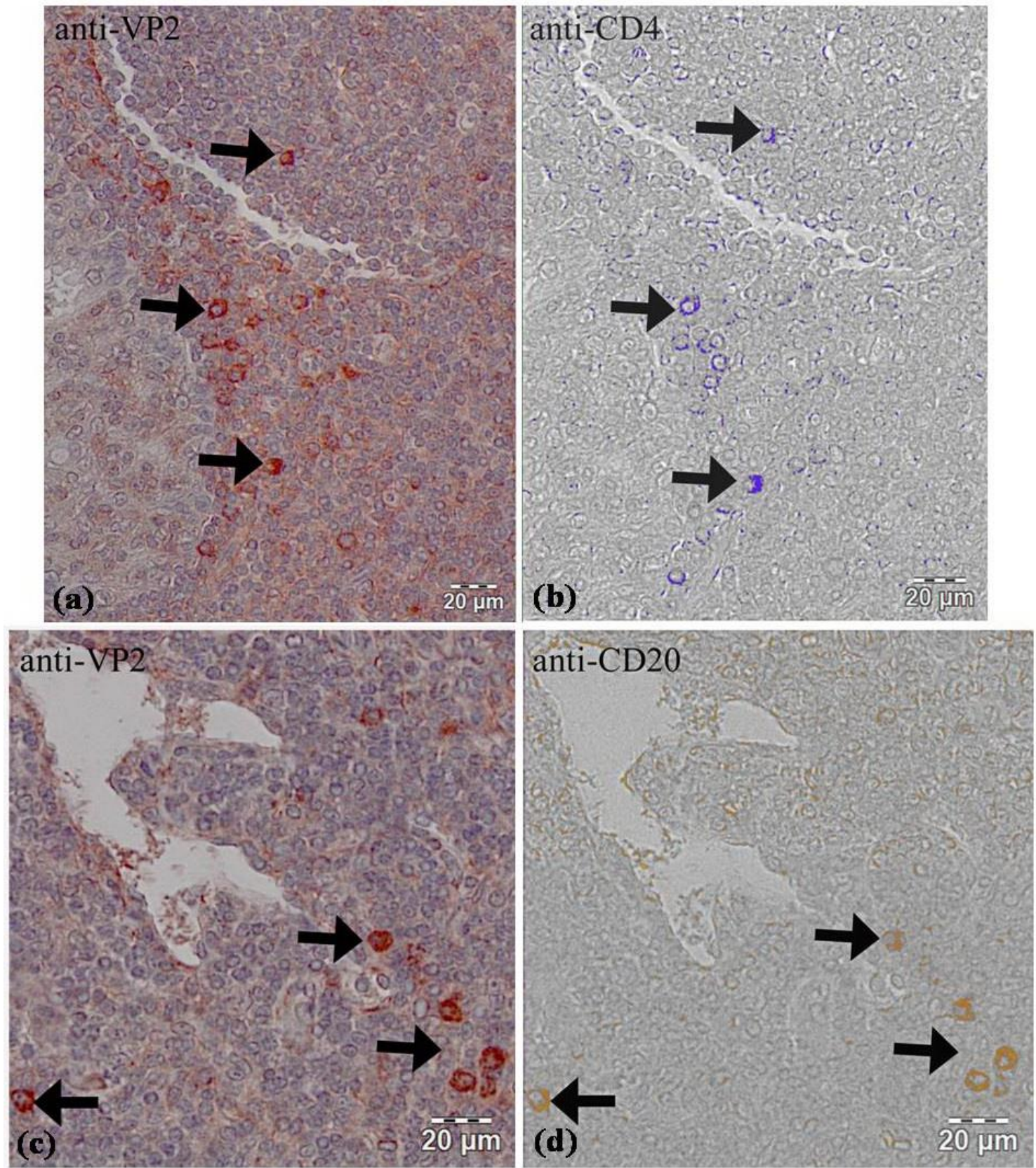

Figura 9. Marcação seqüencial de IHQ pela estratégia de SIMPLE em tonsilas infectadas com RV. (a)

Células de adenoide marcadas com anticorpo anti-VP2 e contracoloração feita com hematoxilina de Harris; (b) células da mesma região do mesmo corte marcadas com anti-CD4 (pseudo-coloridas em azul) após subtração do sinal para VP-2; (c) células de adenoide marcadas com anti-VP2 e contracoloração feita com hematoxilina de Harris; (d) células da mesma região do mesmo corte marcadas com CD20 (pseudocoloridas em laranja) após a subtração do sinal de VP-2. Imagens adquiridas em Scan Scope VS120 Olympus. 


\subsection{Localização da replicação de RV em tonsilas humans por Hibridização in situ}

A hibridação in situ com sondas de LNA para RV mostrou ser específica para antigenoma de RV, tendo mostrado positividade para 2 sorotipos testados (RV-16 e RV-1A), e não para vírus Coxsackie em coágulos de célula HeLa infectadas in vitro (Figura 11). Nenhum sinal de positividade foi observado nos controles negativos nem nos coágulos de HeLa infectada com COXA9. Em 12 preparações histológicas utilizando seis tecidos positivos exclusivamente para RV, documentamos replicação ativa de RV em todos, em concordância com os resultados de qPCR.

A hibridação mostrou-se localizada, com sinal do fluoróforo DyLigth 594 exclusivamente em células do epitélio pavimentoso e na região extra-folicular de adenoides. Não foi verificado sinal de hibridação com sonda para antigenoma no interior de folículos linfoides (Figura 10). 


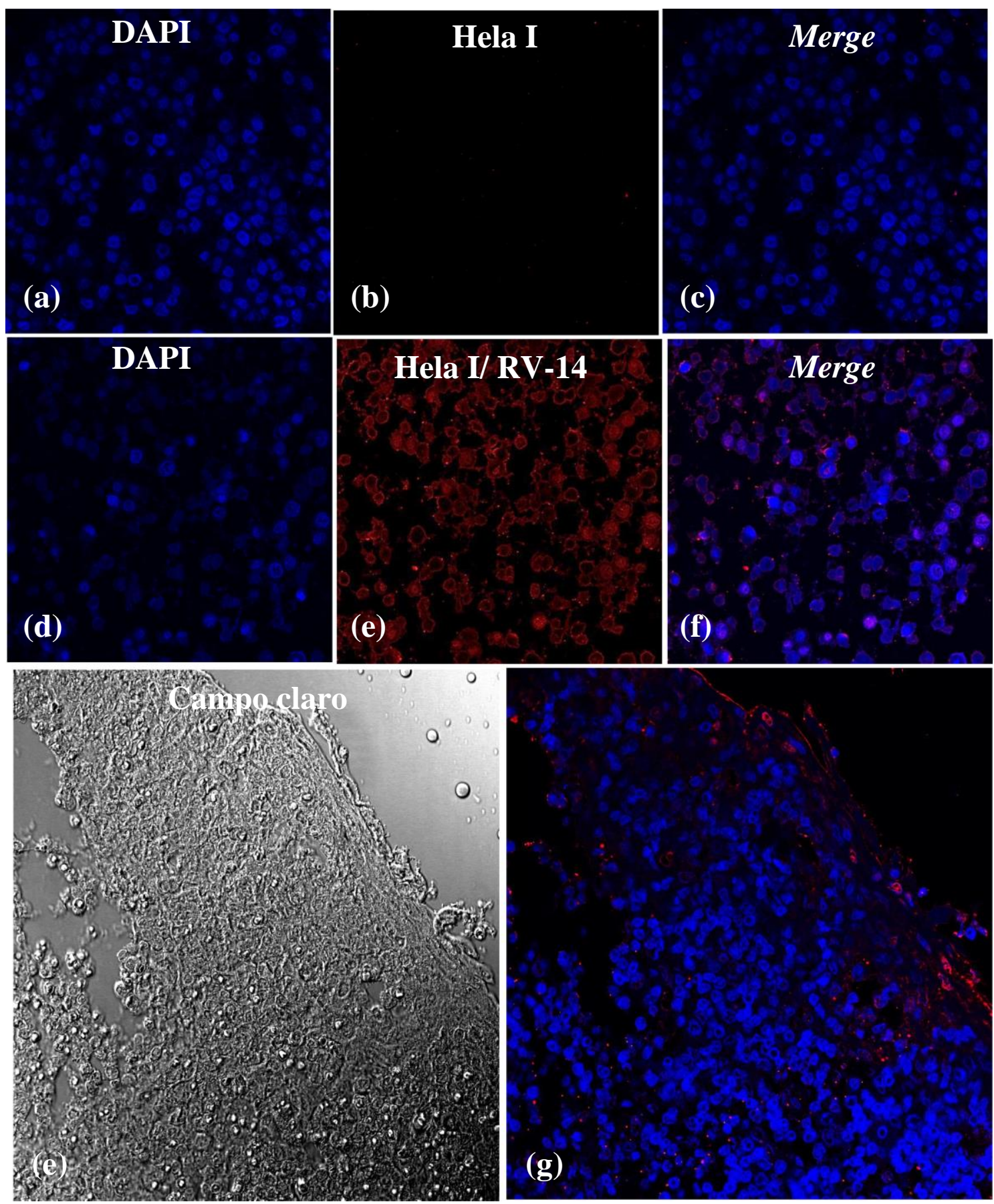

Figura 10. Hibridação in situ para antigenoma de rinovírus. Em (a) (b) e (c) marcação nuclear por DAPI com ausência de sinal de hibridação com sonda para RNA(-) marcada com Alexa 594 em controle negativo (coágulo de Hela não infectada); Em (e) (f) e (g) marcação nuclear por DAPI, com sinal positivo de hibridação com sonda para RNA(-) marcada com Alexa 594 e merge das imagens, em controle positivo (coágulo de Hela infectada com RV-14). Em (g) e (h) campo claro e marcação positiva de hibridização com sonda para o RNA(-) de RV em corte parafinado de adenoide hipertrófica. Presença do antigenoma (intermediário replicativo) na porção do epitélio pseudoestratificado e região extra-folicular do tecido. Imagens adquiridas em microscópio confocal Leica TCS SP5 (aumento $63 \mathrm{x}$ ). 


\subsection{Infecção ex vivo de explantes de tonsilas humanas por $R V-16$}

Os explantes derivados de amígdalas e adenoides (Figura 11c e Figura 11d) foram mantidos por até 14 dias em cultivo sem perda da viabilidade, como evidenciaram a formação de extenso crescimento de outgrowth de epitélio e de fibroblastos. Constatamos que a arquitetura tecidual dos explantes tonsilares foi preservada, apesar do diminuto tamanho dos fragmentos e do tempo de cultivo utilizado para realizar as inoculações virais com RV-16. Os resultados indicaram que RV-16 infectou os explantes cultivados de adenoides, como evidenciado pela marcação da proteína estrutural VP-2 em células do epitélio ciliado dessas adenoides, e também em células do interior do mesmo tecido, sugerindo que pode haver invasão viral do tecido linfoide a partir do epitélio tonsilar (Figura 11g, Figura 11h e Figura $12 a)$.

Os resultados indicam também que houve infecção produtiva nos explantes, considerando a constatação de replicação viral pela marcação com anticorpo contra dsRNA (mAb-J2) nos mesmos cortes de tecido, pela estratégia de SIMPLE (Figura 12b). Dessa forma, podemos afirmar que o modelo ex vivo de infecção de fragmentos de tonsilas humanas com RV sustenta a infecção viral, com replicação ao longo de pelo menos três dias pósinoculação com RV-16. 

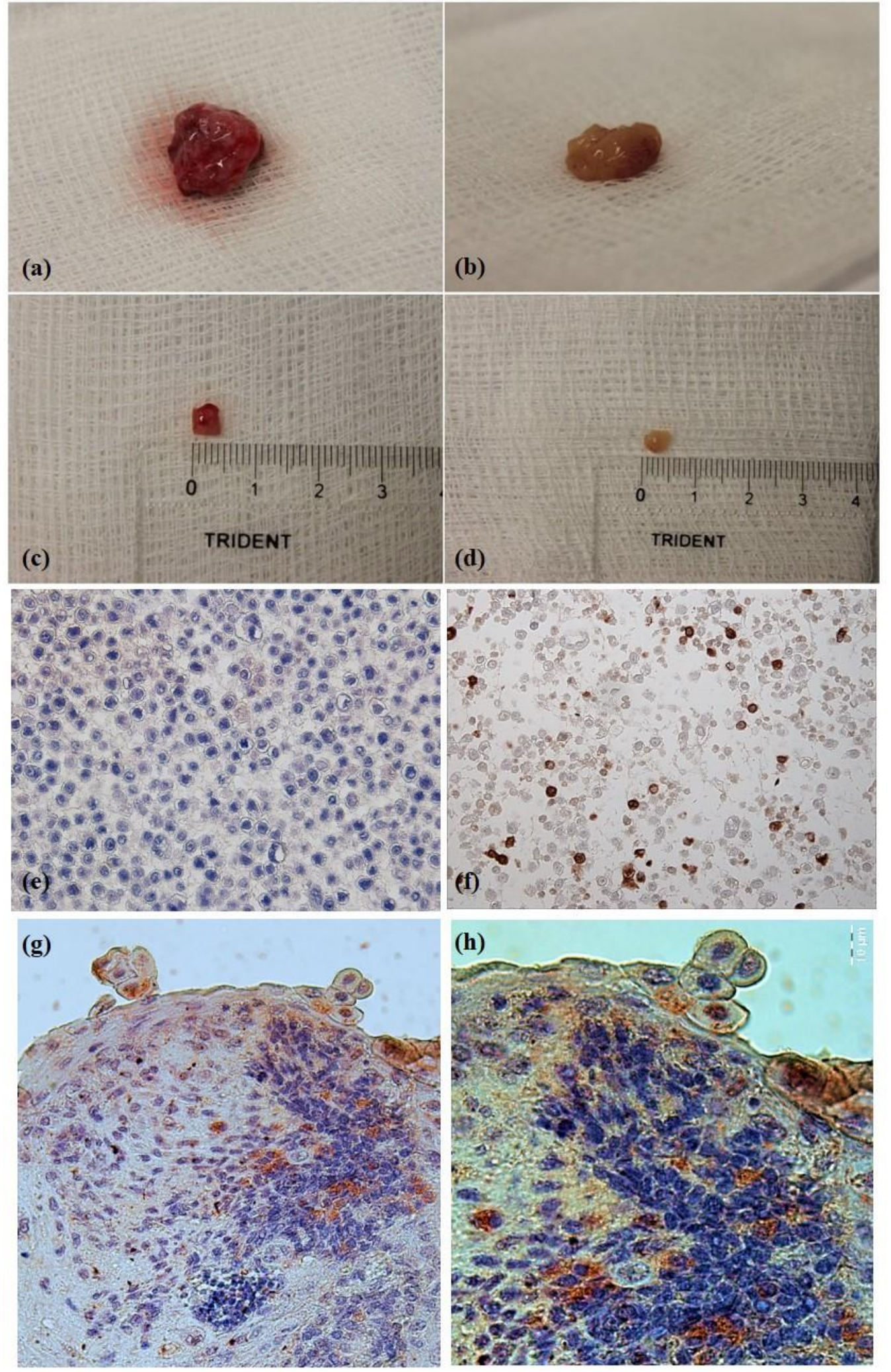

Figura 11. Infecção ex vivo de explantes de adenoide com RV-16. Em (a) (b) (c) e (d) tonsilas humanas e fragmentos de tecidos $\left(5 \mathrm{~mm}^{3}\right)$ utilizados para cultivo ex vivo em placas de cultura transwell de amigdalas e adenoides, respectivamente. Em (e) e (f) controles negativos e positivos da marcação com anti-VP2 realizada por IHQ revelada com Nova Red em coágulo de Hela I não infectada e Hela I infectada com RV-16, respectivamente. Em (g) marcação positiva para VP-2 detectada no epitélio escamoso estratificado e focalmente em células linfoides da região extra-folicular 
de adenoide infectada com RV-16 ex vivo (400X). Em (h) marcação da mesma região do tecido em aumento de $1000 \mathrm{X}$.

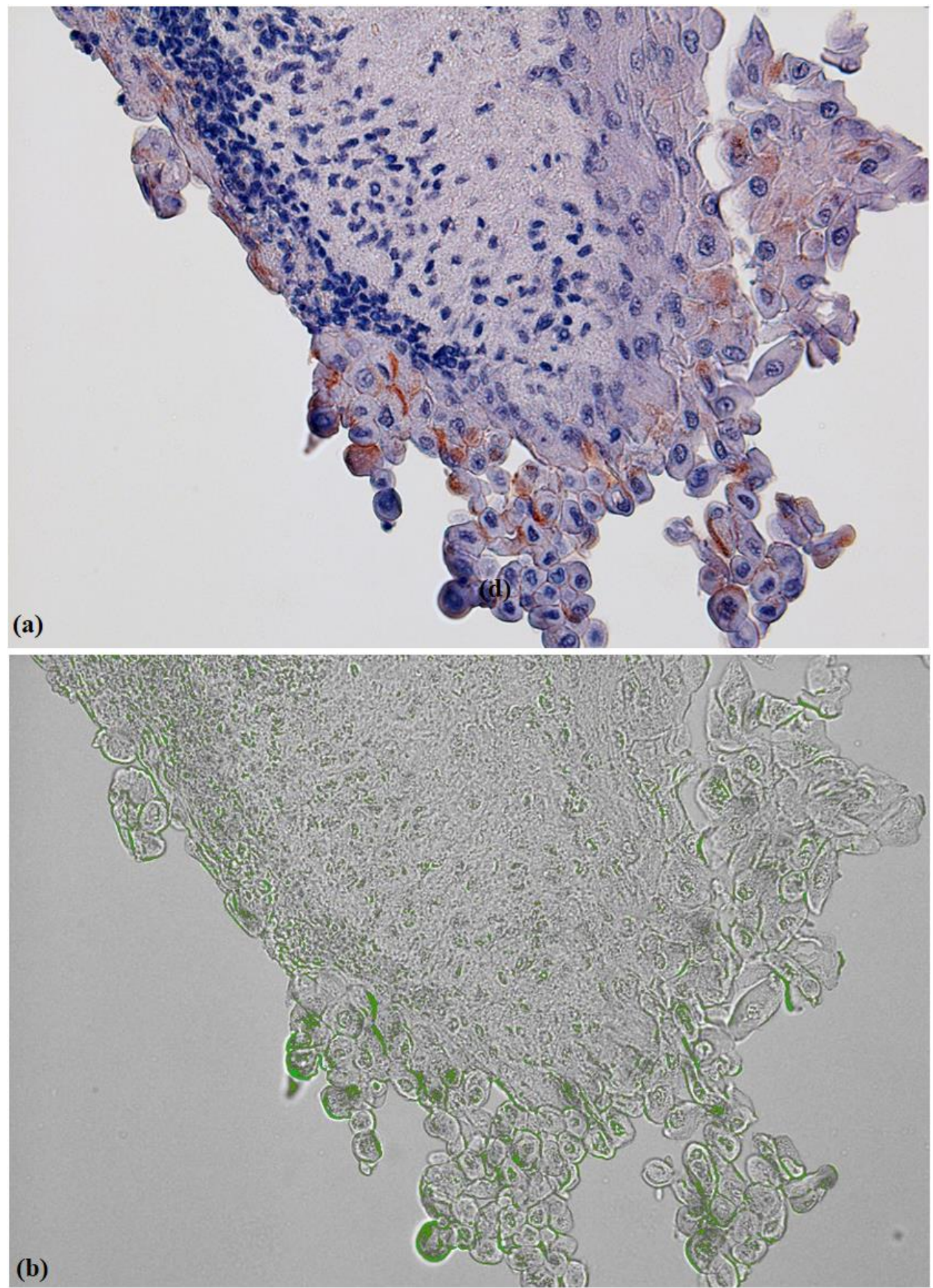

Figura 12. Marcação por IHQ de explante infectado ex vivo com RV-16. Em (a) marcação para VP-2 com contracoloração por hematoxilina de Harris; (b) marcação sequencial por SIMPLE para dsRNA com pseudocor verde, no mesmo corte de explante, após subtração do sinal para VP-2. 


\subsection{Infecção e replicação de cutura primária de CLMN com RV}

Utilizando culturas primárias de CLMN de tonsilas negativas para RV e EV, infectadas in vitro com RV-16 (MOI = 1), foi observado que 24h pós-inoculação proteína estrutural viral foi detectada nas células dispersadass de tonsilas hipertróficas, confirmado por RIFI com anticorpo anti-VP1.

Para avaliar atividade replicativa de RV em culturas de CLMN infectadas in vitro, títulos virais foram mensurados por TCID 50 em monocamadas de células HeLa, separadamente em células e nos sobrenadantes ao longo de 24. Entre 2 a 24 horas pósinoculação houve aumento nos títulos RV-16 em culturas de CLMN de adenoides e amígdalas, com substancial produção de vírus extracelular (Figura 13).

Simultaneamente, investigamos os fenótipos de CLMNs obtidas por dispersão e infectadas in vitro com RV-16 por IF e análise em microscopia confocal, utilizando anticorpos para proteínas virais e marcadores de tipos de células linfóides. Houve colocalização de VP-2 com células CD4 + e células CD20 +, ratificando resultados obtidos por IHQ nos cortes de tonsilas naturalmente infectadas (Figura 14). Houve co-marcação para proteína VP-2 de RV com células CD8 +, células CD56 + e células CD33 +. Foram feitas culturas de células dendríticas imaturas mediante diferenciação CLMNs dispersas com IL-4 e GM-CSF, mas não foi possível detectar RV-16 em células CD123 +. 
(a)

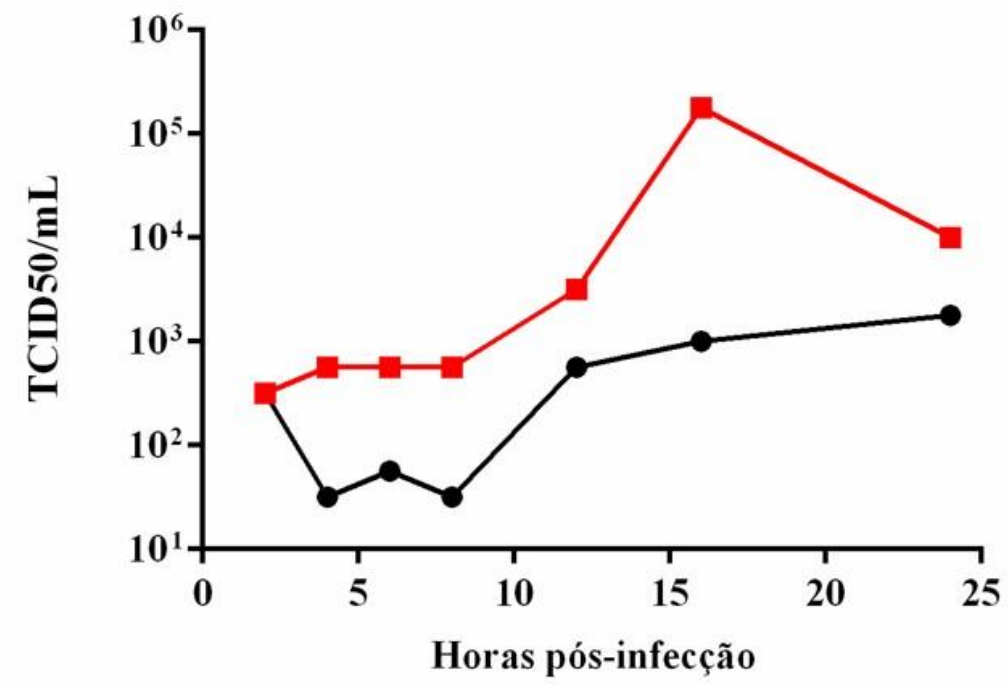

(b)

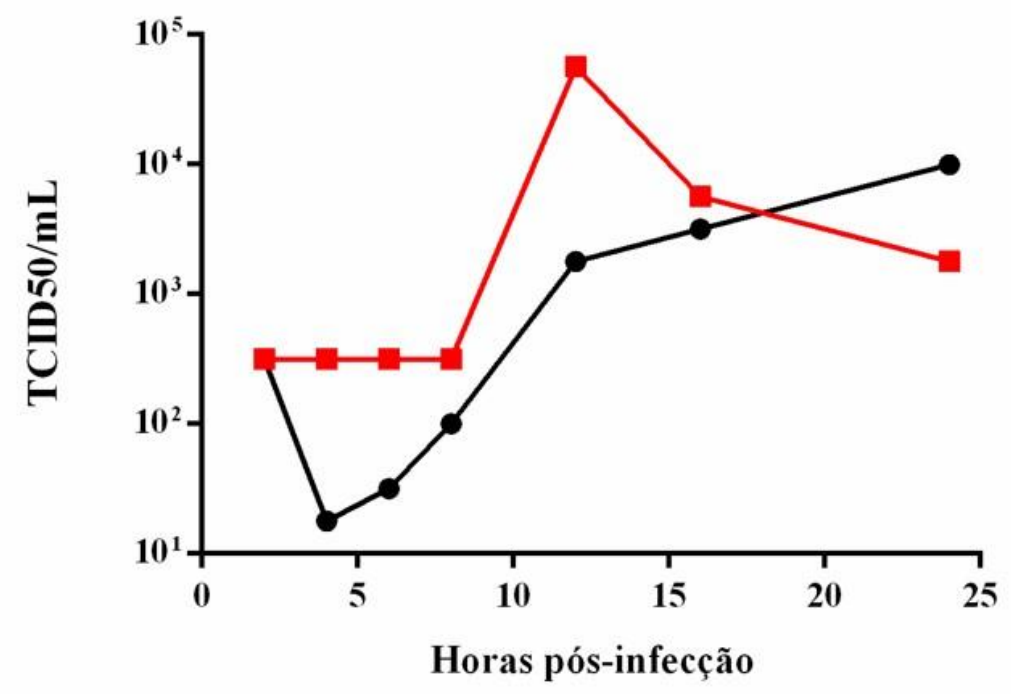

Figura 13. Titulação por $\mathrm{TCID}_{50}$ de $\mathrm{RV}-16$ inoculado em CLMN in vitro $(\mathrm{MOI}=1)$, nos tempos de 2 , 4, 6, 8, 12, 16 e 24 horas pós-infecção. Em (a) títulos de RV-16 em CLMN dispersadas de adenoide; (b) títulos de RV-16 em CLMN dispersadas de amígdalas. 


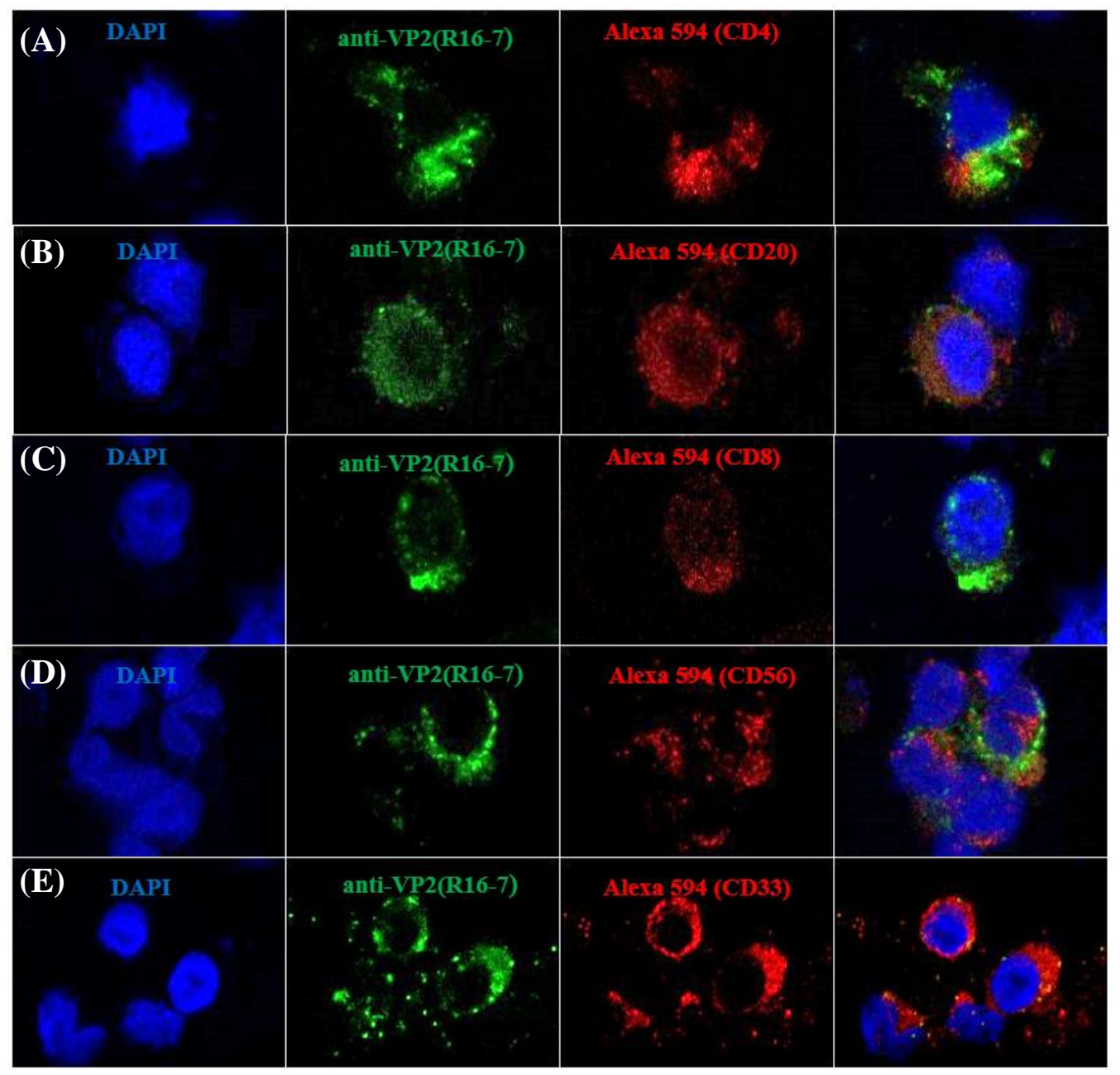

Figura 14. Imunofluorescência de CLMN infectadas in vitro com RV-16. No painel (A), célula marcada positivamente para VP-2 e para CD4; No painel (B), célula marcada para VP-2 e CD20; No painel (C), célula marcada para VP-2 e CD8; No painel (D), célula marcada para VP-2 e CD56; No painle (E), célula marcada para VP-2 e CD33. Núcleos marcados com DAPI. Aumento de 630X, com zoom 2X. Imagens adiquiridas em microscópio Confocal SP5 Leica.

\subsection{Isolamento de RV de tecidos e SNF.}

Foram utilizadas amostras de 17 pacientes, todos positivos exclusivamente para RV por qPCR, para realizar isolamento de vírus viáveis. No total, foram sete amígdalas, 17 adenoides e 6 SNFs inoculados em culturas de fibroblastos WI-38 e HeLa. Foi possível recuper isolados de 4 dos 17 pacientes (23\%), tanto nos tecidos de adenoides quanto em secreções. Foi observado efeito citopático característico (Figura 15b e Figura15d) e confirmação por IF. Controles foram lâminas de células Hela I não infectadas e infectadas com RV-16, utilizadas em todas os ensaios (Figura 15e e Figura 15f). Cada isolado foi confirmado pela positividade por IF para proteína VP-1 (Figura 16). Em dois isolados foi possível sequenciar a região 5' NTR, que permitiu confirmar o mesmo tipo de RV no tecido e 
na secreção: foi detectado RV-4 (espécie B, grupo major) em amostras de tecido e secreção de um paciente, e RV-73 (espécie A, grupo major) em outro paciente.
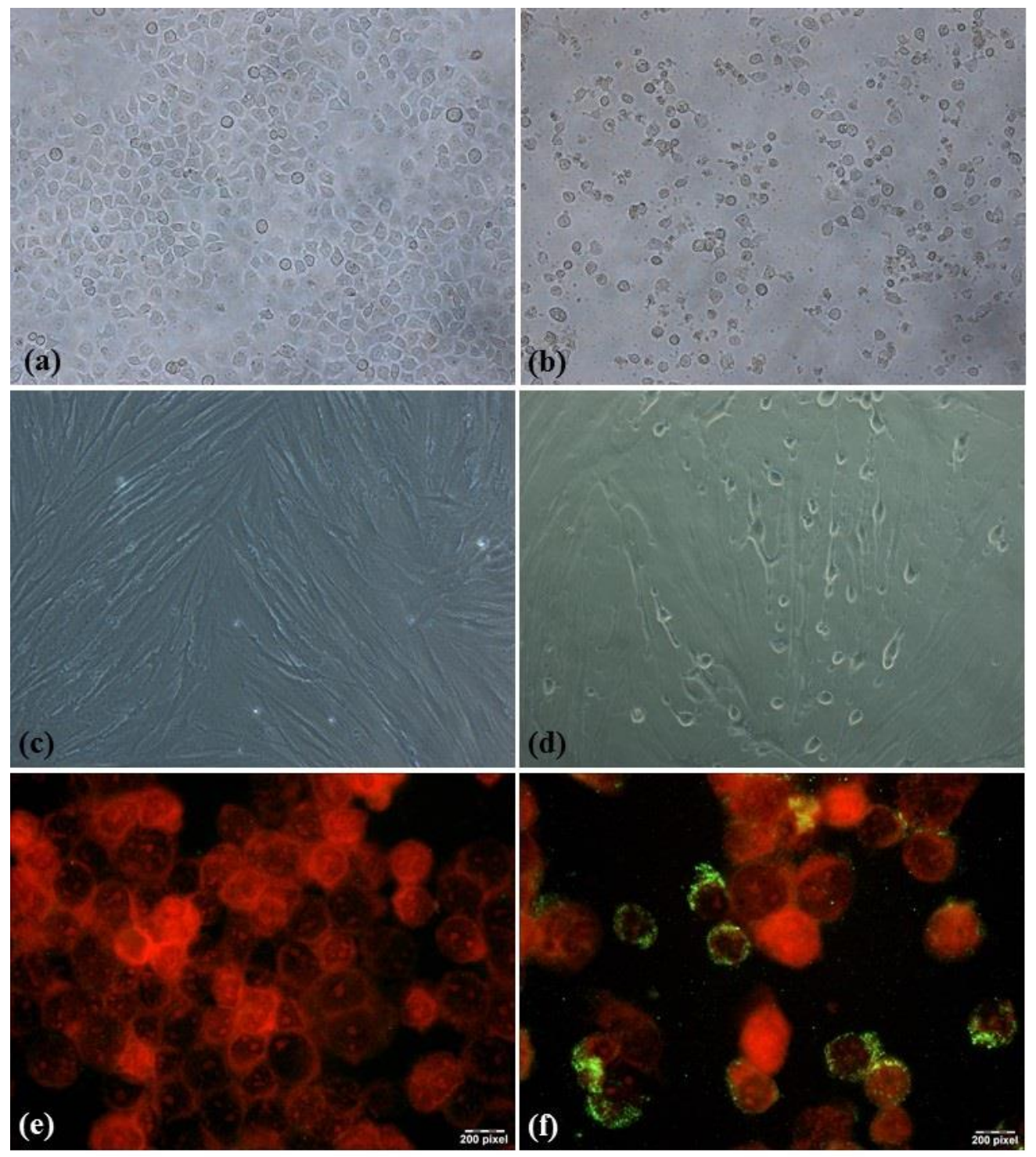

Figura 15. Isolamento de RV em culturas de células. (a) Monocamada de células Hela normal; (b) efeito citopático de RV em células Hela inoculadas com SNF; (c) Monocamada de células WI-38 normal; (d) efeito citopático de RV em células WI-38 inoculadas com tecido; (e) Controle negativo de IF; (f) Controle positivo de IF:células Hela infectadas com RV-16. Contracoloração feita com azul de Evans (Aumento de 400x). 


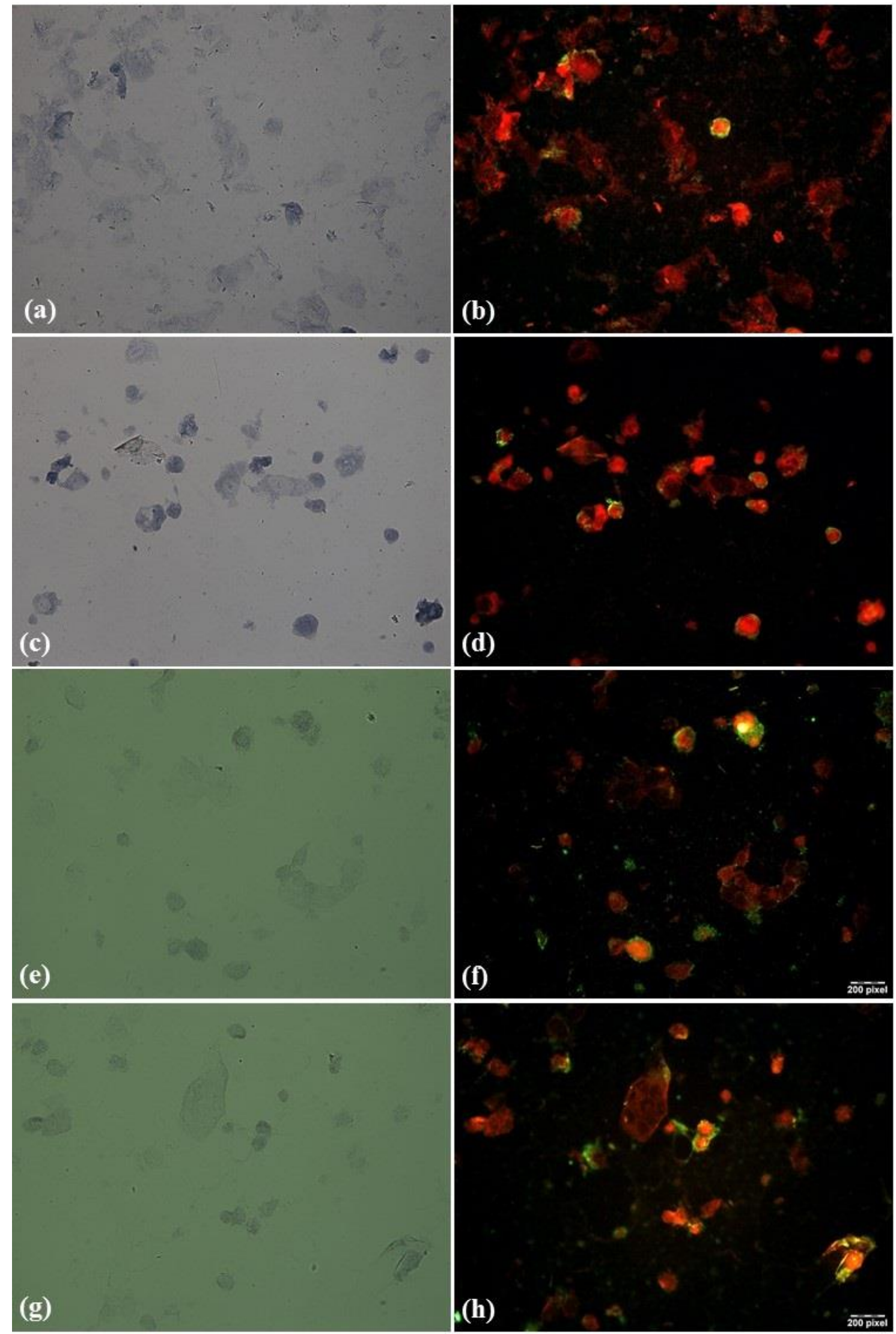

Figura 16. Marcação positiva por RIFI com anti-VP1 de isolados virais recuperados em células Hela I e WI-38. Contracoloração com Azul de Evans. Aumento de 400x. 


\section{DISCUSSÃO}

Ao que sabemos, o presente estudo é o mais extenso já feito sobre infecção por RV em tecidos tonsilares e secreções respiratórias de crianças sem sintomas de IRA.

Com base nas evidências até agora disponíveis, é bem aceito que o sítio primário de infecção por RV é o epitélio da nasofaringe, onde a replicação viral inicial acontece desencadeando expressão de genes da resposta inflamatória imediata cujos efeitos incluem aumento de expressão de receptores de RV no epitélio nasal, para onde mais tarde ocorre espalhamento da infecção. Por extensão, a infecção pode acometer os epitélios de revestimento de seios da face, tuba auditiva e ouvido médio (Arruda et al., 1995). De fato, vários estudos mostraram a presença de genoma de RV no interior do seio maxilar, no ouvido médio de crianças com otite média crônica com efusão, em células epiteliais de cornetos nasais de pacientes com sinusite crônica, bem como até no trato respiratório inferior (Arruda et al., 1991, Pitkaranta et al., 1997, Pitkaranta et al., 1998, Jang et al., 2006, Papadopoulos et al., 2000).

Estudos anteriores feitos pelo nosso grupo e por outros grupos de pesquisa indicam a presença inusitada de genoma de RV em tonsilas humanas de pacientes com hipertrofia tonsilar crônica (Proença-Modena et al., 2012, Rihkanen et al., 2004; Suvilehto et al., 2006, Biill et al., 2014, Jartti et al., 2014). No entanto, não havia ainda um estudo mais detalhado da distribuição dos tipos celulares albergando RV em tonsilas naturalmente infectadas.

No presente estudo, quando tomamos em conjunto as evidências de replicação ativa de $\mathrm{RV}$ em tonsilas, como a detecção de antigenoma in situ, e o isolamento de RV em culturas celulares, é possível inferir que $14.4 \%$ de indivíduos com hipertrofia adenotonsilar, e sem sintomas de infecção aguda, têm infecção ativa assintomática por RV, e não somente a detecção de genoma viral por PCR, que poderia ser remanescente de uma infecção pregressa. Este foi um dos mais importantes achados deste estudo, pois clareia um longo debate sobre o significado de detectar RV por RT-PCR, como único vírus ou em meio a múltiplas codetecções, em secreções nasofaríngeas de pessoas assintomáticas. Infelizmente, por razões óbvias, não temos acesso a tecidos de tonsilas completamente normais para estudos in situ. No entanto, em um estudo anterior (dados não publicados), um grupo controle de 20 biópsias obtidas por micro-punch de adenoides de crianças sem hipertrofia tonsilar, mas cuja manipulação da adenoide tornou-se necessária no acesso cirúrgico para implantar cóclea 
como tratamento de surdez congênita, RV foi detectado por RT-PCR em $16.6 \%$ das adenoids testadas. Reiteramos que não foi possível determinar marcadores de replicação naqueles pequenos fragmentos de punch, mas a mera detecção por RT-PCR levanta a possibilidade de que haja replicação ativa, mesmo que somente em algumas daquelas crianças, o que ampliaria a importância de adnoides como reservatórios de RV. As amígdalas e a adenoide constituem a maior parte do tecido linfóde que forma o anel de Waldeyer, assim desempenhando importante papel na primeira linha de defesa contra patógenos que utilizam a via aéria superior como porta de entrada (Brandtzaeg, 2003). É, portanto, plausível considerar esses tecidos como sítios importantes de infecção por vírus respiratórios. Ao analisar as frequências de detecção de RV em cada tonsila, observamos taxa de infecção de adenoide significativamente maior em comparação com amígdalas ( $p<0.005)$, indicativo de sua maior susceptibilidade a infecção por RV. É possível, porém, que isso se deva ao acesso facilitado que RV têm à adenoide em comparação com amígdalas, em virtude da principal via de aquisição de RV ser a cavidade nasal.

$\mathrm{O}$ achado de RV em atividade replicativa no interior de tecidos de adenóides e amígdalas de indivíduos sem sintomas de infecção aguda por este agente, levanta a tentadora possibilidade de que esses tecidos linfoepiteliais podem servir como sítios de infecção persistente como descrito para o vírus do sarampo em humanos (Anlar et al., 2002) e para o vírus da febre aftosa em bovinos (Juleff et al., 2008).

Observações feitas em estudos anteriores mostraram replicação de RV em células do epitélio respiratório em culturas ex vivo de adenoides (Arruda et al 1991). Os dados presentes corroboram o achado de replicação demonstram novamente que o RV é capaz de se replica ativamente em amigdalas de adenoids de pacientes com doenças adenotonsilar crônica, comprovado pela presença de marcadores moleculares de replicação através de ensaios de hibridização in situ para o intermediário replicativo RNA(-), pela detecção de dsRNA dos explantes de adenoides infectados ex vivo e pela considerável produção de progênie observada nas titulações das CLMN infectadas in vitro com RV-16, que em conjunto provam a susceptibilidade e permissividade das tonsilas humanas à infecção por RV.

A análise dos resultados de marcação por IHQ levam a crer que a produção de proteínas estruturais de RV encontra-se amplamente distribuída nos diferentes compartimentos dos tecidos linfoides. Nossos resultados indicaram que não somente o epitélio ciliado das fossas adenoidanas e epitélio pseudoestratificado das criptas amigdalianas 
foram positivos para as proteínas VP-1 e VP-2 de RV, o que já era esperado levando em conta que o RV cuja reputação de infectar o epitélio respiratório do trato superior já está bem descrita, mas também indicaram a produção de proteínas estruturais virais em outras células presentes no tecido linfóide, ao longo da região folicular extra-folicular e abaixo da zona do manto, no interior de folículos linfóides secundários.

Um achado notável deste estudo foi a localização in situ das células sede da produção de proteínas estruturais de RV nas tonsilas naturalmente infectadas. Os fenótipos das células onde houve marcação positiva de VP-2 foram células CD4 ${ }^{+}$e células B CD20 ${ }^{+}$. Nossos achados vão ao encontro com dados disponíveis da infecção d RV em diferentes tipos de leucócitos utilizando infecção in vitro de sangue periférico (PBMC). É bem conhecido o papel protetor das células $\mathrm{T}\left(\mathrm{CD}^{+}\right)$em resposta a uma variedade de vírus respiratórios, incluindo RV (Parry et al., 2000; Hogan et al., 2001). A presença de VP-2 em células CD4 em nossos experimentos pode ser indicativo de células de memória presentes nas tonsilas que , após nova exposição a um RV, são responsáceis por um clearence viral mais rápido e eficiente.

De qualquer forma, foi descrito que RV infecta células T de PBMC, com expressão transiente de proteína estrutural VP-2, e no mesmo estudo foi demonstrado que o vírus ativou células $\mathrm{T} \mathrm{CD}^{+}{ }^{+} \mathrm{CD} 8^{+}$mesmo na depleção de células apresentadoras de antígenos (APCs) (Ilarraza et al., 2013). Recentemente, demonstrou-se pela primeira vez que RV infecta, forma fabricas virais e ativa forte proliferação de células B derivadas de PBMCs humanos (Aab et al., 2017). Em asmáticos, resultados indicam que linfócitos T e B estão diretamente envolvidos na gravidade de quadros de exacerbações de crise de asma induzida pela infecção por RV (Zhu et al., 2014). É razoável considerar que a infecção do RV em linfócitos T e B de tonsilas humanas ativa vias inflamatórias que predispõem a hipertrofia observada nesses tecidos, fenômeno que estaria em sinergia com o efeito pró-inflamatório decorrente da infecção de outros patógenos co-infectando o mesmo tecido, como outros vírus e bactérias.

Adicionalmente, a infecção in vitro de CLMN por RV-16 resultou na identificação dos seguintes fenótipos celulares expressando VP-2: células linfoides $\mathrm{CD}^{+}, \mathrm{CD}^{+}, \mathrm{CD}^{+}, \mathrm{CD} 20^{+}$,

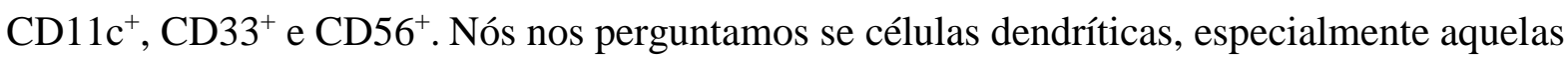
residentes em criptas tonsilares, poderiam servir de via de entrada para a invasão de RV nas tonsilas humanas, no entanto, não foi observado células dendríticas CD123+ ${ }^{+}$infectadas por RV-16 em nossos experimentos. Nossos resultados de infecção in vitro devem ser analisados com cautela, uma vez que a infecção experimental com adição exogena de estoques virais em 
culturas de CLMN dispersas não reflete o microambiente observado no interior das tonsilas infectadas por RV, e portanto, não representa o curso natural da infecção, além de anular o possível papel de células epiteliais no delivering de partículas virais à células linfoides subjacente. Vários vírus respiratórios infectam células imunes do hospedeiro, consequentemente atrasando ou desativando as respostas antivirais do hospedeiro e aumentando assim as chances de sucesso de replicação viral. A cerca do RV, muito se sabe a respeito do vírus infectar, replicar e produzir progenie infecciosa em PBMC (Gern et al., 1995; Ilarraza et al., 2013; Zhu et al., 2014; Steinke et al., 2015; Aab et al., 2017), porem as investigações sobre as infecção em células linfoides encontram-se limitada à comprovação da detecção de genoma viral ou presença de intermediário replicativo.

Nossos achados a cerca de replicação de RV em tosilas humanas foram reproduzidos através dos nossos experimentos com explantes de adenoides, uma vez que as mesmas células nas quais se vizualizou marcação positiva para proteína estrutural VP-2, também foi visualizado marcação positiva para dsRNA, utilizando anticorpo anti-J2. Podemos afirmar, portanto, que explantes de tonsilas humanas sustentam a infecção in vitro com RV-16, sendo possível detectar proteína estrutural no epitélio estratificado esquamoso e focalmente em algumas células residentes da região extra-folicular. A padronização de um modelo ex vivo utilizando tecido linfoide infectado com RV-16 ganha importância extra tendo em vista que modelos animais são limitados a estudo com rinovírus do grupo minor ou rinovírus do grupo major utilizando camundongos transgênicos, sendo que em ambos os casos não há desenvolvimento de doença nos animais (Bartlett et al., 2015). Assim portanto e possível aplicar o modelo de infecção ex vivo no estudos de novos agentes antivirais, tendo em visto que em função dos mais de 150 genótipos de RV circulantes até o momento, é virtualmente impossível desenvolver uma vacina contra esse agente.

Finalmente, evidenciamos a produção de vírions infecciosos de RV nos tecidos linfoides infectados sendo possível recuperar RV de secreções respiratórias e tonsilas dos mesmos pacientes. Utilizando combinação de tipos celulares (HeLa-I e WI-38) a fim de aumentar a sensibilidade do ensaio de isolamento de acordo com Arruda et al., 1996. O isolamento de RV foi confirmado por presença de CPE e marcação positiva por RIFI utilizando anticorpo anti-VP1, sendo em seguida realizado o sequenciamente dos isolados a fim de analisar o genótipo viral isolado em cada especimem. Embora tenha sido possível sequenciar RV em um número restrito de SNF e tecidos, a ocorrência do mesmo tipo de vírus nas amostras de um mesmo paciente sugere mais uma vez que RV é capaz de replicar dentro 
das tonsilas humans humanas, com produção de progênie infecciosa, colocando definitivamente as tonsilas hipertróficas como reservatórios de RV e sítios de excreção viral, portanto, evidenciando a sua importância em relação a transmissão de RV na comunidade e na infecção do próprio paciente portador da tonsila hiperplásica infectada com RV. 


\section{CONCLUSÃO}

Em conclusão, amígdalas e adenoides hipertróficas humanas são sítios de replicação e propagação de RV. Se elevada freqüência de detecção de genoma RV no tecido tonsilar, especialmente nas adenoids, reflete a presença de vírus infeccioso em um padrão crônico de infecção, ou é apenas um remanescente de infecção prévia, ainda é obscuro. Todavia, nossos resultados inserem tonsilas hipertróficas de indivíduos asintomáticos para IRA como uma possível fonte muito importante de RV na comunidade, uma vez que o mesmo vírus detectado no tecido é encontrado viável nas secreções respiratórias. Tomados em conjunto, nossos achados representam desafios para a compreensão dos mecanismos pelos quais RV são capazes de contornar a resposta imune inata para permanecer dentro dos órgãos linfóides órgãos, os quais deveriam controlar estas infecções. Finalmente, é necessário investigar os mecanismos e as consequiências envolvidas na replicação de rinovírus em tecidos linfóides do trato respiratório superior e investigar a presença do virus nos demais orgãos linfóides do corpo humano. 


\section{REFERÊNCIAS BIBLIOGRÁFICAS}

Aab A, Wirz O, van de Veen W, Söllner S, Stanic B, Rückert B, Aniscenko J, Edwards MR, Johnston SL, Papadopoulos NG, Rebane A, Akdis CA, Akdis M. Human rhinoviruses enter and induce proliferation of B lymphocytes. Allergy. 2017 Feb;72(2):232-243.

Alexopoulou, L.; Holt, A.C.; Medzhitov, R.; Flavell, R.A. Recognition of double-stranded RNA and activation of NF-кB by toll-like receptor 3. Nature 2001, 413, 732-738.

Andrews CH, Chaproniere DM, Gompels AE, Pereira HG, Roden AT. Propagation of common-cold virus in tissue cultures. Lancet.1953;265(6785):546-7.

Anlar B, Ayhan A, Hotta H, Itoh M, Engin D, Barun S, Koseoglu O. Measles virus RNA in tonsils of asymptomatic children. Journal of paediatrics and child health. 2002. 38:424-425.

Arruda E, Boyle TR, Winther B, Pevear DC, Gwaltney JM, Jr., Hayden FG. Localization of human rhinovirus replication in the upper respiratory tract by in situ hybridization. 1995. J Infect Dis 171:1329-33,

Arruda E, Crump CE, Marlin SD, Merluzzi VJ, Hayden FG. In vitro studies of the anti rhinovirus activity of soluble intercellular adhesion molecule-1. Antimicrob Agents Chemother.1992;36(6):1186-91.

Arruda E, Crump CE, Rollins BS, Ohlin A, Hayden FG. Comparative susceptibilities of human embryonic fibroblasts and HeLa cells for isolation of human rhinoviruses. $\mathrm{J}$ Clin Microbiol. 1996 May;34(5):1277-9.

Arruda E, Mifflin TE, Gwaltney JM Jr, Winther B, Hayden FG. Localization of rhinovirus replication in vitro with in situ hybridization. $\mathrm{J}$ Med Virol.1991;34(1):38-44.

Baj A, Colombo M, Headley JL, McFarlane JR, Liethof MA, Toniolo A. Post-poliomyelitis syndrome as a possible viral disease. $\mathrm{nt} J$ Infect Dis. 2015;35:107-16.

Bartlett NW, Singanayagam A, Johnston SL. Mouse models of rhinovirus infection and airways disease. Methods Mol Biol. 2015;1221:181-8.

Bell S, Howard A, Wilson JA, Abbot EL, Smith WD, Townes CL, Hirst BH, Hall J. Streptococcus pyogenes infection of tonsil explants is associated with a human $\beta$ defensin 1 response from control but not recurrent acute tonsillitis patients. Mol Oral Microbiol. 2012;27(3):160-71.

Bernstein JM, Yamanaka N, Nadal D. Immunobiology of the tonsils and adenoids. In: Ogra P, Lamm ME, McGhee JR, Mestecky J, Strober W and Bienenstock J (Eds). Handbook of mucosal Immunology. San Diego, Academic Press, Inc. 1994. 
Biill OV, Lourenço EA, Passos SD. Detection of respiratory viruses in nasopharyngeal swab and adenoid tissue from children submitted to adenoidectomy: pre- and postoperative analysis. Int Arch Otorhinolaryngol. 2014 Apr;18(2):150-4.

Bochkov YA, Watters K, Ashraf S, Griggs TF, Devries MK, Jackson DJ, Palmenberg AC, Gern JE. Cadherin-related family member 3, a childhood asthma susceptibility gene product, mediates rhinovirus $\mathbf{C}$ binding and replication. Proc Natl AcadSci U S A. 2015.

Brandtzaeg P .The B-cell development in tonsillar lymphoid follicles. Acta Otolaryngol Suppl (Stockh). 1996, 523:55-59

Brandtzaeg P. Immunology of tonsils and adenoids: everything the ENT surgeon needs to know. Int J Pediatr Otorhinolaryngol. 2003 Dec;67 Suppl 1:S69-76.

Buttinelli G, Donati V, Fiore S, Marturano J, Plebani A, Balestri P, Soresina AR, Vivarelli R, Delpeyroux F, Martin J, Fiore L. Nucleotide variation in Sabin type 2 poliovirus from an immunodeficient patient with poliomyelitis. J Gen Virol. 2003;84(Pt 5):1215-21.

Chantzi, F.M.; Papadopoulos, N.G.; Bairamis, T.; Tsiakou, M.; Bournousouzis, N.; Constantopoulos, A.G.; Liapi, G.; Xatzipsalti, M.; Kafetzis, D.A. Human rhinoviruses in otitis media with effusion. Pediatr. Allergy Immunol. 2006, 17, 514-518.

Chapuis F, Rosenzwajg M, Yagello M, Ekman M, Biberfeld P, Gluckman JC. Differentiation of human dendritic cells from monocytes in vitro. Eur J Immunol. 1997 Feb;27(2):431-41.

Cohen SG. Asthma in antiquity: the Ebers Papyrus. Allergy Proc. 1992;13(3):147-54.

Colbere-Garapin F, Christodoulou C, Crainic R, Pelletier I. Persistent poliovirus infection of human neuroblastoma cells. Proc Natl Acad Sci U S A 1989;86:7590-4.

Colbere-Garapin F, Duncan G, Pavio N, Pelletier I, Petit I. An approach to understanding the mechanisms of poliovirus persistence in infected cells of neural or non-neural origin. Clin Diagn Virol 1998;9:107-13.

Dils RR. Explants and disaggregated tissue preparations as model systems in nutritional research: advantages and pitfalls. Proc Nutr Soc.1984;43(2):133-40.

Dochez AR, Mills KC, Kneeland Y. Studies on the common cold:VI. Cultivation of the virus in tissue medium. $\mathrm{J}$ Exp Med. 1936 Mar 31;63(4):559-79.

Engelmann I, Mordacq C, Gosset P, Tillie-Leblond I, Dewilde A, Thumerelle C, Pouessel G, Deschildre A. Rhinovirus and asthma: reinfection, not persistence. Am J Respir Crit Care Med. 2013;188(9):1165-7.

Feuer R, Mena I, Pagarigan RR, Hassett DE, Whitton JL. Coxsackievirus replication and the cell cycle: a potential regulatory mechanism for viral persistence/latency. Med Microbiol Immunol. 2004;193(2-3):83-90. 
Flint S, Enquist, LW, Racaniello VR, Skalka, AM. Genomes and Genetics, p. 52, Principles of Virology, 3 ed, vol. 2. 2009. ASM Press, Whashington, DC.

Gebert A. The role of $M$ cells in the protection of mucosal membranes. Histochem Cell Biol. 1997; 108:455-470

Gern JE, Dick EC, Lee WM, Murray S, Meyer K, Handzel ZT, Busse WW. Rhinovirus enters but does not replicate inside monocytes and airway macrophages. J Immunol. 1996;156(2):621-7.

Gern JE, Palmenberg AC. Rhinoviruses. In: Knipe DM and Howley PM (Eds) Fields Virology (6 ${ }^{\text {th }}$ Ed) Wolters Kluwer, Philadelphia, 2013. pp. 531-549

Glass G, Papin JA, Mandell JW. SIMPLE: a sequential immunoperoxidase labeling and erasing method. J Histochem Cytochem. 2009; 57:899-905.

Himeda T, Hosomi T, Okuwa T, Muraki Y, Ohara Y. Saffold Virus Type 3 (SAFV-3) Persists in HeLa Cells. PLoS One. 2013; 8(1): e53194.

Himeda T, Ohara Y. Saffold Virus, a Novel Human Cardiovirus with Unknown Pathogenicity. J Virol. 2012; 86(3): 1292-1296.

Hofer F, Gruenberger M, Kowalski H, Machat H, Huettinger M, Kuechler E, Blaas D. Members of the low density lipoprotein receptor family mediate cell entry of a minorgroup common cold virus. ProcNatlAcad Sci. 1994;91(5):1839-42.

Hogan, R. J., W. Zhong, E. J. Usherwood, T. Cookenham, A. D. Roberts, and D. L. Woodland. Protection from respiratory virus infections can be mediated by antigenspecific CD4(+) T cells that persist in the lungs. J. Exp. Med. 2001; 193: 981-986.

Ilarraza R,Wu Y,Skappak CD,Ajamian F,Proud D,AdamkoDJ. Rhinovirus has the unique ability to directly activate human T cells in vitro. $\mathbf{J}$ Allergy ClinImmunol.2013;131(2):395404.

International Commitee on Taxonomy of Viruses, 2015 release. Disponível em: http://www.ictvonline.org/virusTaxonomy.asp. Acesso em 15 de Dezembro de 2016.

Jacobs SE, Lamson DM, St George K, Walsh TJ. Human rhinoviruses. ClinMicrobiol Rev. 2013;26(1):135-62.

Jaidane H, Gharbi J, Lobert PE, Lucas B, Hiar R, M'Hadheb M B, Brilot F, Geenen V, Aouni $\mathrm{M}$, Hober D. Prolonged viral RNA detection in blood and lymphoid tissues from coxsackievirus B4 E2 orally-inoculated Swiss mice. Microbiology and immunology. 2006;50:971-974.

Jang, Y.J.; Kwon, H.J.; Park, H.W.; Lee, B.J. Detection of rhinovirus in turbinate epithelial cells of chronic sinusitis. Am. J. Rhinol. 2006, 20, 634-636.

Jans DA, Ghildyal R. Rhinoviruses. Methods Mol Biol. 2015;1221:v-vii. 
Jansen RR, Wieringa J, Koekkoek SM, Visser CE, Pajkrt D, Molenkamp R, de Jong MD, Schinkel J. Frequent detection of respiratory viruses without symptoms: toward defining clinically relevant cutoff values. J Clin Microbiol. 2011;49(7):2631-6.

Jartti T, Lehtinen P, Vuorinen T, Koskenvuo M, Ruuskanen O. Persistence of rhinovirus and enterovirus RNA after acute respiratory illness in children. $J$ Med Virol 2004;72:695-699.

Jartti T, Palomares O, Waris M, Tastan O, Nieminen R, Puhakka T, Rückert B, Aab A, Vuorinen T, Allander T, Vahlberg T, Ruuskanen O, Akdis M, Akdis CA. Distinct regulation of tonsillar immune response in virus infection. Allergy. 2014;69(5):658-67.

Johnston SL, Sanderson G, Pattemore PK, Smith S, Bardin PG, Bruce CB, Lambden PR, Tyrrell DA, Holgate ST. Use of polymerase chain reaction for diagnosis of picornavirus infection in subjects with and without respiratory symptoms. J Clin Microbiol 1993;31:111-117.

Jorgensen S, Baker A, Moller S, Nielsen BS. Robust one-day in situ hybridization protocol for detection of microRNAs in paraffin samples using LNA probes. Methods. 2010; 52:375-381.

Juleff N, Windsor M, Reid E, Seago J, Zhang Z, Monaghan P, Morrison IW, Charleston B. Foot-and-mouth disease virus persists in the light zone of germinal centres. PLoS One. 2008;3(10):e3434.

Kaiser L, Aubert JD, Pache JC, Deffernez C, Rochat T, Garbino J, Wunderli W, Meylan P, Yerly S, Perrin L, Letovanec I, Nicod L, Tapparel C, Soccal PM. Chronic rhinoviral infection in lung transplant recipients. Am J Respir Crit Care Med. 2006;174(12):1392-9.

Kandolf R, Sauter M, Aepinus C, Schnorr JJ, Selinka HC, Klingel K. Mechanisms and consequences of enterovirus persistence in cardiac myocytes and cells of the immune system. Virus Res. 1999;62(2):149-58.

Kennedy JL, Turner RB, Braciale T, Heymann PW, Borish L. Pathogenesis of rhinovirus infection. Curr Opin Virol. 2012; 2(3):287-93.

Kistler AL, Webster DR, Rouskin S, Magrini V, Credle JJ, Schnurr DP, e cols. Genome-wide diversity and selective pressure in the human rhinovirus. Virol Journal 2007; 4: 40-59.

Kurnatowski P, Putynski L, Lapienis M, Kowalska B. Physical and emotional disturbances in children with adenotonsillar hypertrophy. The Journal of laryngology and otology. 2008;122:931-935.

Lau SK, Yip CC, Tsoi HW, et al. Clinical features and complete genome characterization of a distinct human rhinovirus (HRV) genetic cluster, probably representing a previously undetected HRV species, HRV-C, associated with acute respiratory illness in children. J ClinMicrobiol. 2007;45(11):3655-64. 
Lee WM, Kiesner C, Pappas T, Lee I, Grindle K, Jartti T, Jakiela B, Lemanske RF, Jr., Shult PA, Gern JE. A diverse group of previously unrecognized human rhinoviruses are common causes of respiratory illnesses in infants. PloS one. 2007;2:e966.

Lehner M, Holter W. Endotoxin-free purification of monocytes for dendritic cell generation via discontinuous density gradient centrifugation based on diluted FicollPaque Plus. Int Arch Allergy Immunol. 2002;128(1):73-6.

Leigh, R., \& Proud, D. Modulation of epithelial biology by rhinovirus infection: Role in inflammatory airway diseases. Future Virol. 2011;6, 375-386.

Lessler J, Reich NG, Brookmeyer R, et al. Incubation periods of acute respiratory viral infections: a systematic review. Lancet Infect Dis. 2009;9(5):291-300.

Lewis-Rogers N, Bendall ML,Crandall KA. Phylogenetic relationships and molecular adaptation dynamics of human rhinoviruses. MolBiolEvol.2009; 26(5):969-81.

Linder JE, Kraft DC, Mohamed Y, Lu Z, Heil L, Tollefson S, Saville BR, Wright PF, Williams JV, Miller EK. Human rhinovirus C: Age, season, and lower respiratory illness over the past 3 decades. J Allergy ClinImmunol. 2013;131(1):69-77.

Loeffelholz MJ, Trujillo R, Pyles RB, Miller AL, Alvarez-Fernandez P, Pong DL, Chonmaitree T. Duration of rhinovirus shedding in the upper respiratory tract in the first year of life. Pediatrics. 2014;134(6):1144-50.

Malcolm E, Arruda E, Hayden FG, Kaiser L. Clinical features of patients with acute respiratory illness and rhinovirus in their bronchoalveolar lavages. J Clin Virol. 2001;21(1):9-16.

Malmstro K, Pitkaranta A, Carpen O, Pelkonen A, Malmberg LP, Turpeinen M, Kajosaari M, Sarna S, Lindahl H, Haahtela T, Makela MJ. Human rhinovirus in bronchial epithelium of infants with recurrent respiratory symptoms. J Allergy Clin Immunol. 2006; 118: 591-6.

Marlovits TC, Abrahamsberg C, Blaas D. Very-low-density lipoprotein receptor fragment shed from HeLa cells inhibits human rhinovirus infection. J Virol. 1998;72(12):10246-50.

McErlean P, Shackelton LA, Lambert SB, et al. Characterisation of a newly identified human rhinovirus, HRV-QPM, discovered in infants with bronchiolitis. J ClinVirol. 2007;39(2):67-75.

McIntyre CL, Knowles NJ, Simmonds P. Proposals for the classification of human rhinovirus species $\mathrm{A}, \mathrm{B}$ and $\mathrm{C}$ into genotypically assigned types. $\mathrm{J}$ GenVirol. 2013;94(Pt 8):1791-806.

Nave H, Gebert A, Pabst R. Morphology and immunology of the human palatine tonsil. Anat Embryol (Berl). 2001;204(5):367-73.

Oldstone MB. Anatomy of viral persistence. PLoS Pathog. 2009 Jul;5(7):e1000523. 
Oliveira MA, Zhao R, Lee WM, Kremer MJ, Minor I, Rueckert RR, Diana GD, Pevear DC, Dutko FJ, McKinlay MA, et al. The structure of human rhinovirus 16. Structure. 1993;1(1):51-68.

Palmenberg AC,Spiro D,Kuzmickas R,Wang S,Djikeng A,Rathe JA,Fraser-Liggett $\mathrm{CM}$,Liggett $\mathrm{SB}$. Sequencing and analyses of all known human rhinovirus genomes reveal structure and evolution. Science.2009; 324(5923):55-9.

Palmenberg AC. The Language of Life. Annu Rev Virol. 2016 Sep 29;3(1):1-28.

Papadopoulos, N.G.; Bates, P.J.; Bardin, P.G.; Papi, A.; Leir, S.H.; Fraenkel, D.J.; Meyer, J.; Lackie, P.M.;Sanderson, G.; Holgate, S.T.; et al. Rhinoviruses infect the lower airways. J. Infect. Dis. 2000, 181, 1875-1884.

Parry, D.E; Busse, W.W; Sukow, K.A; Dick, C.R; Swenson, C; Gern, J.E. Rhinovirusinduced PBMC responses and outcome of experimental infection in allergic subjects. $\mathrm{J}$. Allergy Clin. Immunol. 2000;105: 692-698.

Paul AV. Possible Unifying Mechanism of Picornavirus Genome Replication. Em: Semler BL and Wimmer E, eds. Molecular Biology of Picornaviruses. Washington: ASM Press; 2002: 227-46.

Pegtel DM, Middeldorp J, Thorley-Lawson DA. Epstein-Barr virus infection in ex vivo tonsil epithelial cell cultures of asymptomatic carriers. J Virol. 2004;78(22):12613-24.

Pelletier I, Duncan G, Colbère-Garapin F. One amino acid change on the capsid surface of poliovirus sabin 1 allows the establishment of persistent infections in HEp-2c cell cultures. Virology. 1998;241(1):1-13.

Pelon W, Mogabgab WJ, Phillips IA, et al. A cytopathogenic agent isolated from naval recruits with mild respiratory illness. Proc Soc Exp Biol Med (1957); 94: 262-7.

Perez S, Inman M, Doster A, Jones C. Latency-related gene encoded by bovine herpesvirus 1 promotes virus growth and reactivation from latency in tonsils of infected calves. J ClinMicrobiol. 2005;43(1):393-401.

Perry M, Whyte A. Immunology of the tonsils. Immunol. 1998; $19414-421$.

Piralla A, Zecca M, Comoli P, Girello A, Maccario R, Baldanti F. Persistent rhinovirus infection in pediatric hematopoietic stem cell transplant recipients with impaired cellular immunity. J Clin Virol. 2015;67:38-42.

Pitkäranta A, Virolainen A, Jero J, Arruda E, Hayden FG. Detection of rhinovirus, respiratory syncytial virus, and coronavirus infections in acute otitis media by reverse transcriptase polymerase chain reaction. Pediatrics. 1998;102(2 Pt 1):291-5.

Pitkaranta, A.; Arruda, E.; Malmberg, H.; Hayden, F.G. Detection of rhinovirus in sinus brushings of patients with acute community-acquired sinusitis by reverse transcriptionPCR. J. Clin. Microbiol. 1997; 35, 1791-1793. 
Price WH. The isolation of a new virus associated with respiratory clinical disease in humans. Proc Natl Acad Sci. 1956; 42: 892-6.

Proenca-Modena JL, Pereira Valera FC, Jacob MG, Buzatto GP, Saturno TH, Lopes L, Souza JM, Escremim Paula F, Silva ML, Carenzi LR, Tamashiro E, Arruda E, Anselmo-Lima WT. High rates of detection of respiratory viruses in tonsillar tissues from children with chronic adenotonsillar disease. PLoS One. 2012;7(8):e42136.

Racaniello VR. Piconaviridae: The Viruses and Their Replication. Em: Knipe DH, Howley PM, eds. Fields Virology, Vol. 1 ( $6^{\circ}$ Ed). Filadélfia: Lippincott Williams e Wilkins; 2013: 453-489.

Rihkanen H, Carpén O, Roivainen M, Vaheri A, Pitkäranta A. Rhinovirus in adenoid tissue. Int J Pediatr Otorhinolaryngol. 2004;68(7):903-8.

Rossmann MG, Arnold E, Erickson JW, Frankenberger EA, Griffith JP, Hecht HJ, Johnson JE, Kamer G, Luo M, Mosser AG, et al. Structure of a human common cold virus and functional relationship to other picornaviruses. Nature. 1985;317(6033):145-53.

Roush KS, Domiati-Saad RK, Margraf LR, Krisher K, Scheuermann RH, Rogers BB, Dawson DB. Prevalence and cellular reservoir of latent human herpesvirus 6 in tonsillar lymphoid tissue. American journal of clinical pathology. 2001; 116:648-654.

Royston L, Tapparel C. Rhinoviruses and Respiratory Enteroviruses: Not as Simple as ABC. Viruses. 2016;8(1).

Sajjan, U.; Wang, Q.; Zhao, Y.; Gruenert, D.C.; Hershenson, M.B. Rhinovirus disrupts the barrier function of polarized airway epithelial cells. Am. J. Respir. Crit. Care Med. 2008; $178,1271-1281$.

Santos RI, Almeida MF, Paula FE, Rodrigues AH, Saranzo AM, Paula AE, Silva ML, Correa VM, Acrani GO, Neder L, Arruda E. Experimental infection of suckling mice by subcutaneous inoculation with Oropouche vírus. Virus Res. 2012; 170:25-33.

Schaerli P, Willimann K, Lang AB, Lipp M, Loetscher P, Moser B. CXC chemokine receptor $\mathbf{5}$ expression defines follicular homing $\mathbf{T}$ cells with $\mathrm{B}$ cell helper function. $\mathrm{J}$ Exp Med. 2000; 192: 1553-1562.

Simmonds P, McIntyre C, Savolainen-Kopra C, Tapparel C, Mackay IM, Hovi T. Proposals for the classification of human rhinovirus species $\mathbf{C}$ into genotypically assigned types. $\mathrm{J}$ Gen Virol. 2010;91(10):2409-19.

Stanway G. Structure, function and evolution of picornaviruses. J Gen Virol. 1990;71 (11):2483-501.

Steinke JW, Liu L, Turner RB, Braciale TJ, Borish L. Immune surveillance by rhinovirusspecific circulating CD4+ and CD8+ T lymphocytes. PLoS One. 2015;10(1):e0115271. 
Stenfors LE, Bye HM, Raisanen S. Noticeable differences in bacterial defence on tonsillar surfaces between bacteria-induced and virus-induced acute tonsillitis. Int J Pediatr Otorhinolaryngol. 2003;67(10):1075-82.

Suvilehto J, Roivainen M, Seppanen M, Meri S, Hovi T. Rhinovirus/enterovirus RNA in tonsillar tissue of children with tonsillar disease. J ClinVirol. 2006; 35(3):292-7.

Tracy S, Smithee S, Alhazmi A, Chapman N. Coxsackievirus can persist in murine pancreas by deletion of 5 ' terminal genomic sequences. J Med Virol. 2015;87(2):240-7.

Turner RB, Cough RB. Rhinoviruses, cap. 26. In: KNIPE, AM; HOWLEY, PM [Eds]. Fields Virology $\left(5^{\text {th }}\right.$ Ed). Philadelphia: Lippincott Willians\& Wilkins - Wolters Kluwer Business, 2007; pp. 895-906.

Unger, B.L.; Ganesan, S.; Comstock, A.T.; Faris, A.N.; Hershenson, M.B.; Sajjan, U.S. Nodlike receptor $\mathrm{X}-1$ is required for rhinovirus-induced barrier dysfunction in airway epithelial cells. J. Virol. 2014, 88, 3705-3718.

van Benten I, Koopman L, Niesters B, Hop W, van Middelkoop B, de Waal L, van Drunen K, Osterhaus A, Neijens H, Fokkens W. Predominance of rhinovirus in the nose of symptomatic and asymptomatic infants. Pediatr Allergy Immunol. 2003 Oct;14(5):363-70.

Van Cauwenberge, P.B.; van Kempen, M.J.; Bachert, C. The common cold at the turn of the millennium. Am. J. Rhinol. 2000, 14, 339-343.

Whitton JL, Cornell CT, Feuer R. Host and virus determinants of picornavirus pathogenesis and tropism. Nature reviews. Microbiology. 2005; 3:765-776.

Winther, B.; Gwaltney, J.M.; Hendley, J.O. Respiratory virus infection of monolayer cultures of human nasal epithelial cells. Am. Rev. Respir. Dis. 1990, 141, 839-845.

Wood LG, Powell H, Grissell TV, Davies B, Shafren DR, Whitehead BF, Hensley MJ, Gibson PG. Persistence of rhinovirus RNA and IP-10 gene expression after acute asthma. Respirology. 2011;16(2):291-9.

Zhang PC, Pang YT, Loh KS, Wang DY.

Comparison of histology between recurrent tonsillitis and tonsillar hypertrophy. Clin Otolaryngol Allied Sci. 2003;28(3):235-9.

Zhu J, Message SD, Qiu Y, Mallia P, Kebadze T, Contoli M, Ward CK, Barnathan ES, Mascelli MA, Kon OM, Papi A, Stanciu LA, Jeffery PK, Johnston SL. Airway inflammation and illness severity in response to experimental rhinovirus infection in asthma. Chest. 2014;145(6):1219-29 